\title{
DIGITAL ECONOMICS
}

\author{
Avi Goldfarb \\ Catherine Tucker \\ Working Paper 23684 \\ http://www.nber.org/papers/w23684
}

\author{
NATIONAL BUREAU OF ECONOMIC RESEARCH \\ 1050 Massachusetts Avenue \\ Cambridge, MA 02138 \\ August 2017
}

We thank Andrey Fradkin and Kristina McElheran for helpful comments. We are grateful to the Sloan Foundation for its support of the NBER Digitization Initiative, which built the research community around which this review is based. The views expressed herein are those of the authors and do not necessarily reflect the views of the National Bureau of Economic Research.

NBER working papers are circulated for discussion and comment purposes. They have not been peer-reviewed or been subject to the review by the NBER Board of Directors that accompanies official NBER publications.

(C) 2017 by Avi Goldfarb and Catherine Tucker. All rights reserved. Short sections of text, not to exceed two paragraphs, may be quoted without explicit permission provided that full credit, including (C) notice, is given to the source. 
Digital Economics

Avi Goldfarb and Catherine Tucker

NBER Working Paper No. 23684

August 2017

JEL No. L81,L86,O33

\title{
ABSTRACT
}

Digital technology is the representation of information in bits. This technology has reduced the cost of storage, computation, and transmission of data. Research on digital economics examines whether and how digital technology changes economic activity. In this review, we emphasize the reduction in five distinct economic costs associated with digital economic activity: Search costs, replication costs, transportation costs, tracking costs, and verification costs.

\author{
Avi Goldfarb \\ Rotman School of Management \\ University of Toronto \\ 105 St. George Street \\ Toronto, ON M5S 3E6 \\ CANADA \\ and NBER \\ agoldfarb@ rotman.utoronto.ca \\ Catherine Tucker \\ MIT Sloan School of Management \\ 100 Main Street, E62-533 \\ Cambridge, MA 02142 \\ and NBER \\ cetucker@mit.edu
}




\title{
Digital Economics
}

\section{Avi Goldfarb*and Catherine Tucker ${ }^{\dagger}$}

\author{
July 25, 2017
}

\begin{abstract}
Digital technology is the representation of information in bits. This technology has reduced the cost of storage, computation, and transmission of data. Research on digital economics examines whether and how digital technology changes economic activity. In this review, we emphasize the reduction in five distinct economic costs associated with digital economic activity: Search costs, replication costs, transportation costs, tracking costs, and verification costs.
\end{abstract}

Digital technology is the representation of information in bits. This reduces the cost of storage, computation, and transmission of data. Research on digital economics examines whether and how digital technology changes economic activity.

Understanding the effects of digital technology does not require fundamentally new economic theory. However, it requires a different emphasis. Studying digital economics starts with the question of "what is different?" What is easier to do when information is represented by bits rather than atoms? Digital technology often means that costs that may

*Avi Goldfarb is the Ellison Professor of Marketing at the Rotman School of Management, University of Toronto, and Research Associate at the NBER. We thank Andrey Fradkin and Kristina McElheran for helpful comments. We are grateful to the Sloan Foundation for its support of the NBER Digitization Initiative, which built the research community around which this review is based.

†Catherine Tucker is the Sloan Distinguished Professor of Management Science at MIT Sloan School of Management, Cambridge, MA, and Research Associate at the NBER. 
constrain economic actions. Therefore, digital economics explores how standard economic models change as certain costs fall substantially and perhaps approach zero. We emphasize how this shift in costs can be divided into five types:

\section{Lower search costs}

2. Lower replication costs

\section{Lower transportation costs}

\section{Lower tracking costs}

\section{Lower verification costs}

Search costs are lower in digital environments, enlarging the potential scope and quality of search. Digital goods can be replicated at zero cost, meaning they are often non-rival. The role of geographic distance changes as the cost of transportation for digital goods and information is approximately zero. Digital technologies make it easy to track any one individual's behavior. Last, digital verification can make it easier to verify the reputation and trustworthiness of any one individual, firm, or organization in the digital economy. Each of these cost changes draws on a different set of well-established economic models: Primarily search models, non-rival goods models, transportation cost models, price discrimination models, and reputation models.

Early research tested straightforward models of lower costs. For example, the search literature of the late 1990s and early 2000s built directly on earlier models by Diamond (1971) and Varian (1980). As we detail below, empirical work emerged that found some inconsistencies with the simple models, and so richer models and empirical analysis of the cost reductions developed to take account of the subtleties of the digital context.

Other authors have also emphasized the role of lower costs for digital economics (e.g. Shapiro and Varian (1998), Borenstein and Saloner (2001), Smith et al. (2001), etc.) Ellison 
and Ellison (2005) the implications of these lower search and transportation costs for industrial organization with respect to increasing returns, distance and two-sided markets. Since their article, the digital economics literature has grown to contribute to the economics of crime, the economics of public goods, organizational economics, finance, urban economics, labor economics, development economics, health economics, political economy, media economics, public finance, and international economics. In this sense, we view digital economics as a way of thinking that touches many fields of economics.

This review starts with a brief history of digital technology and the internet. It will then discuss each of the cost changes associated with digitization. In each section, we emphasize the key research questions that have driven the area and how they have evolved, and relate them to policy where applicable. After discussing each cost change, we finish by discussing the consequences of digitization for countries, regions, firms, and individuals.

\section{Digital Technology: A Brief History}

The history of modern computing begins not with the internet but in 1945 with the commercialization of technologies developed during World War II (Ceruzzi, 2003). These first machines focused on rapid calculation with little capacity for storing and retrieving information. By the early 1950s, magnetic core memories enabled efficient digital information storage and perhaps the first real non-arithmetical benefit of representing information in bits emerged: The lower marginal cost of reproducing information. Over time, storage technology, software, and hardware improved so that information processing and reproduction became widespread. The software and hardware industries grew rapidly (Ceruzzi, 2003; Campbell-Kelly, 2004).

Limited communication between computers limited their effect on the economy. It was with the rise of the internet-and with it, low-cost, commercial, computer-to-computer communication-that the representation of information in bits began to have a measurable 
effect on multiple markets. This rise was built on key inventions developed by US military funding in the 1960s and 1970s (Hafner and Lyon, 1996; Greenstein, 2015). For example, DARPA funded the invention of packet switching which breaks down a long message into shorter messages that can be sent through the network and then reassembled upon receipt. DARPA-funded researchers also developed the particular packet switching standards that define internet communication: the Transmission Control Protocol/Internet Protocol or TCP/IP. The NSF began managing a network using that protocol in the 1980s, building a reliable infrastructure that was relatively easy to adopt but also restricted to researchers.

Privatization occurred between 1990 and 1995, leading to the modern commercial internet. The commercial internet diffused quickly, with universities playing a key role in the diffusion process (Goldfarb, 2006). There was near-universal availability and widespread adoption in the United States by 2000 (Greenstein, 2000). ${ }^{1}$ Over time, new technologies have been layered on top of the basic TCP/IP-based internet, including browsers, search engines, online shopping, social networks, mobile communications protocols, security standards, customer relationship management systems, and many others. These technologies and others have enabled increased collection and use of data.

During this process there has been an open question of who should control various aspects of commercial internet activity given this historical context of decentralization. Standards are often agreed upon through committees with representatives from industry and academia. Such standards have an influence on which technologies are widely adopted (Rysman and Simcoe, 2008). Therefore, standards setting creates winners and losers. Simcoe (2012) examines the incentives in standards development for one such standard setting organization, the Internet Engineering Task Force, demonstrating that the commercialization of the internet slowed standards development due to competing commercial interests. Given their

\footnotetext{
${ }^{1}$ This rapid speed of diffusion proved useful for identification in the empirical papers examining the impact of the internet on regions, firms, and individuals that we discuss in the penultimate section.
} 
importance, control of hardware and software standards has been controversial.

Echoing this question of control, the earlier literature on the economics of the internet focused on pricing the sending of information and how it varies with interconnection, competition, and the nature of the content (MacKie-Mason and Varian, 1994). In other words, there is a question about the role of internet service providers in controlling access. Laffont et al. (2003) emphasized how the need for interconnection can affect prices and welfare. This literature emphasized network effects and the challenges of interconnection (Cremer et al., 2000; Besen et al., 2001; Laffont et al., 2001; Caillaud and Jullien, 2003).

As data transmission became a key aspect of digital technology, the question of net neutrality has become a central research and policy focus. Net neutrality means that an internet service provider should treat all data in the same way; regardless of the content provider or content, companies cannot pay an internet service provider to have faster speeds. The net neutrality debate asks whether internet service providers should exercise control over content. Put differently, net neutrality is the norm that Netflix pays the same to send a gigabyte of data to one of their customers as a small startup would pay to send data to the same customer. Internet services have had a historic norm of net neutrality, though this has been challenged in recent years by internet service providers and policy makers in the US and globally. The net neutrality literature therefore emphasizes the role of the connection intermediary (Economides and Hermalin, 2012; Bourreau et al., 2015; Choi et al., 2015; Goetz, 2017). As shown by Lee and Wu (2009) and Greenstein et al. (2016) the particulars of the model matter, and the costs and benefits of net neutrality depend on the specific setting.

Thus, a key theme in the history of digital technology is a tension between openness and control. As we discuss below, this tension is at the center of much of the digital policy literature with respect to copyright, privacy, and discrimination. 


\section{Reduction in Search Costs}

Search costs are the costs of looking for information. Every information gathering activity therefore involves search costs. The basic idea with respect to digital economic activity is that it is easier to find and compare information about potential economic transactions online than offline.

At the beginning of the commercial internet, there was much discussion among economics researchers around how a dramatic reduction in search costs might transform the economy by reducing prices, price dispersion, unemployment, vacancies, and inventories. Allan Greenspan argued that the ICT revolution would reduce the severity of business cycles. $^{2}$ The consequences of low search costs were discussed in financial markets (Barber and Odean, 2001), labor markets (Autor, 2001) and retail markets (Borenstein and Saloner, 2001; Bakos, 2001). The ideas in these papers have their roots in the early search literature which modeled search costs as the costs of gathering information (Stigler, 1961; Diamond, 1971; Varian, 1980). Reflecting this early focus and solid base of economic understanding, the literature on the effects of lower digital search costs is more established than the other parts of the digital economics literature.

\subsection{Are prices and price dispersion lower online?}

Low search costs make it easier for consumers to compare prices, putting downward pressure on prices for similar products. This should reduce both prices and price dispersion. Brynjolfsson and Smith (2000) compares prices of books and CDs at four internet-only retailers, four offline retailers, and four 'hybrid' retailers who had both online and offline stores. They identified 20 books and $20 \mathrm{CDs}$, half of which were bestsellers, and half of which were randomly selected among titles popular enough to be sold in most offline stores. They showed

\footnotetext{
2'Information technology has doubtless enhanced the stability of business operations," Federal Reserve Chairman Alan Greenspan, Feb. 261997 testimony before Congress. https://www.federalreserve.gov/ boarddocs/hh/1997/february/testimony.htm
} 
that online prices for these items were substantially lower than offline prices. Relatively low online prices have been shown in a variety of other settings, including insurance (Brown and Goolsbee, 2002), automotive products (Zettelmeyer and Silva-Risso, 2001), and airlines (Orlov, 2011).

However, though prices may be lower, substantial price dispersion remains. Brynjolfsson and Smith (2000) shows this in their online-offline retail study. Baye et al. (2004a) and Baye et al. (2004b) use evidence from thousands of products and prices to document large and persistent online price dispersion. Orlov (2011) finds that the internet increases the intrafirm dispersion of airline prices, but had no impact on interfirm price dispersion. By contrast, the development economics literature measuring the effect of mobile phones on commodity prices suggests that lower search costs reduced price dispersion (Jensen, 2007; Aker, 2010; Parker et al., 2016).

Given evidence of the persistence of price dispersion online, research turned to explore why price dispersion does not disappear. Of course comparison of online products does not always compare apples-to-apples. In comparing book prices, the book may be the same, but the retailer is different. Different retailers offer different quality, different shopping experiences, and different shipping policies. Firms with higher quality may develop stronger brands, and therefore command higher prices (Waldfogel and Chen, 2006).

Firms selling products can also shape the search process. When consumers search, they assess multiple dimensions of information: price, quality, reputation, shipping fees, time to delivery, color, etc. Lynch and Ariely (2000) demonstrates this for online wine purchasing in a laboratory. If price was available on the first page, consumers focused on price. If consumers needed to click further to learn the price, other attributes became more important for purchase decisions. Fradkin (2017) shows that the details of the search process matter in the context of short term accommodation platform Airbnb. Structural estimates of the cost of an extra click in the consumer search process suggest they are larger than might 
be supposed (Honka, 2014; De Los Santos et al., 2012). This means that consumers stop searching sooner than predicted by models that assume search costs close to zero.

In the presence of search costs, and multiple dimensions of information, firms can partly choose which information has the lowest search costs. Ellison and Ellison (2009a) demonstrates that computer memory chip retailers attract customers with low prices at an online price comparison website, and then show customers other (typically higher quality and higher margin) products once they arrive. Using data from Ebay, Dinerstein et al. (2017) emphasizes how the design of the search algorithm on eBay affects markups charged by eBay sellers. More directly, Hossain and Morgan (2006) shows that online sellers often hide shipping fees until the final purchase page. Moshary et al. (2017) shows a similar phenomenon in the information revealed in ticket prices at an online ticket platform.

Therefore, while prices have fallen, price dispersion has persisted. The initial predictions of low price dispersion missed the point that search costs are endogenous, and so firms can manipulate the search process in order to sustain higher margins and prices.

\subsection{How do low search costs affect variety?}

Low search costs may mean that it is easier to find rare and niche products (Yang, 2013). In this case, digital search might lead to an increase in the proportion of sales going to products that are relatively rarely purchased, a phenomenon dubbed 'the long tail' by Anderson (2006). Using data from a retailer with both online and offline channels, Brynjolfsson et al. (2011) documents that the variety of products available, and purchased, online is higher than offline. Low search costs may facilitate discovery of relatively unknown products (Zhang, 2016)..$^{3}$

Low search costs could also generate superstar effects (Rosen, 1981). If there are verti-

\footnotetext{
${ }^{3}$ In addition to search costs, variety may increase because digital technologies can make inventory systems more efficient, meaning firms can hold millions of products, especially for digital goods that have no physical presence. People may also be less inhibited from purchasing non-standard items when purchasing on a screen rather than from a human (Goldfarb et al., 2015).
} 
cally differentiated products, and the marginal cost of production is zero then homogeneous consumers will all agree which product is best and buy it. Consistent with this, Goldmanis et al. (2010) shows that the internet initially led to a relative increase in the number of large offline bookstores and travel agencies.

Bar-Isaac et al. (2012) explains how both superstar and long tail effects may both result from a reduction in search costs. If products are both vertically and horizontally differentiated, a reduction in search costs may lead to an equilibrium where the most popular and highest quality products are produced in high enough quantity to be sold to everyone while niche products are sold through long tail retailers. The increase in tails at the right and left of the distribution comes at the cost of products in the middle.

The degree to which search costs generate more or less variety depends on the search process endogenously chosen by the firm. Recommendation engines are a key aspect of the online search process. Fleder and Hosanagar (2009) demonstrates this, showing that algorithms that emphasize 'people who bought this also bought' move the sales distribution toward superstars. If many people buy Harry Potter, this recommendation engine will recommend Harry Potter to everyone else. In contrast, if the algorithm emphasizes 'people who bought this disproportionately bought', relatively unusual items that demonstrate niche tastes will be sold. Empirically, Tucker and Zhang (2011) documents that popularity information has asymmetrically large effects for niche products.

Popularity information affects sales in general. Many online platforms sort items by popularity and feature popularity prominently, reducing search costs for this type of information. Showing such popularity information affects purchase behavior not only in retail but also online lending (Zhang and Liu, 2012), and online investing (Agrawal et al., 2015).

The effect on welfare of this change in variety is not obvious, and so it has been the subject of a rich discussion in the literature. Lower search costs that lead people to buy the products that more closely match their preferences should increase welfare. Consistent with 
this, Brynjolfsson et al. (2003) shows that increased variety increases consumer surplus.

At the same time, improvements in welfare may be small. The increase in matching of products to preferences is, by definition, marginal. The new products offered are the products on the margin of being produced. The superstar effects may be marginal relative to the consumers who bought products in the middle because they were unwilling to pay search costs. For example, Ershov (2017) shows that a reduction in search costs in the mobile app market reduced average product quality. On balance, however, it also shows that the increase in variety led to a substantial increase in overall welfare despite the incremental nature of the new products.

Aguiar and Waldfogel (2016) argues that this marginal argument misses the substantial uncertainty about product quality for many information goods. In the context of music, they show that several songs and musicians that seem marginal ex ante ended up having substantial sales. Thus, by enabling such music to get produced, digital markets led to a large change in the relative sales of products. Uncertainty in the process meant better and more music was created.

A great deal of attention has focused on the increase in variety in consumption of media in particular. The internet might also enable people to only read information of that reflects their narrow viewpoint; despite the variety, there is no need to search widely. The latter idea has been emphasized by Cass Sunstein as an 'echo chamber' (Sunstein, 2001). Consistent with the idea of wide variety available but consumption in echo chambers, Greenstein and Zhu (2012) examines the bias of Wikipedia and show that, while, on aggregate, Wikipedia has become less politically biased (towards Democrats) over time, the bias of articles has not changed much. Instead, the political bias has mainly dropped because of the arrival of new, relatively right-wing articles.

By contrast, Gentzkow and Shapiro (2011) shows that internet media consumption is more varied than offline media consumption. Thus, in this context, low search costs lead to 
increased variety. Boxell et al. (2017) argues that the internet is unlikely to be responsible for increased polarization of digital content because the increase in polarization is largest for demographic groups with the least internet usage.

Polarized media may be less concentrated, generating incentives for niche sources to intentionally mislead. Allcott and Gentzkow (2017) show that false news stories about the 2016 presidential election were shared tens of millions of times, though they demonstrate the fake news was unlikely to have changed the election outcome. Long before the attention to fake news in the 2016 election, Antweiler and Frank (2004) examines how anonymous, and potentially misleading, online investing advice affects stock prices. Low search costs-in the absence of a reliable quality filter-meant that this information could be more easily found and shared.

Low online search costs have also transformed the way academic research is consumed. McCabe and Snyder (2015) shows that JSTOR led to an increase in citations of included articles at the expense of others. Search costs fell, but because they fell more for some articles than others, it changes the nature of attention to specific articles and ideas. More starkly, Ellison (2011) argues that peer review may be in decline because of low online search costs. In particular, he shows that high-profile researchers do not need to rely on academic journals to disseminate their ideas. They can post online and people will find their work. In other words, similar to the superstar effect in products, low search costs combined with thousands of research articles benefit the superstar researchers.

\subsection{How do low search costs affect matching?}

Reduced search costs facilitate exchange more generally, often enabled by large digital platforms. Dana and Orlov (2014) shows that airlines are better able to fill capacity. Ellison et al. (2014) shows that online buyers are better able to find the specific books they want. Kroft and Pope (2014) finds online search through Craigslist decreased rental apartment 
and home vacancies (though they measure no effect on unemployment). Anenberg and Kung (2015) shows that online search enabled the rise of a market for truck-based mobile restaurants ("food trucks"). To the extent that the literature emphasizing matching is distinct from search, the matching literature emphasizes that both sides of the market engage in the search process.

Related to the above ideas, low search costs are likely to increase the quality of matches between buyers and sellers, firms and workers, etc. The labor economics literature has emphasized that the internet should reduce unemployment and vacancies. Kuhn and Skuterud (2004) finds no effect of internet job search on employment. Kuhn and Mansour (2014) revisits the analysis several years later with updated data and finds that job searchers that used the internet in job search were indeed more likely to match to an employer.

The reduced costs of search have led to the development of online 'peer-to-peer' platforms dedicated to facilitate matching. The variety of such online matching markets is extraordinary: Workers and firms, buyers and sellers, investors and entrepreneurs, vacant rooms and travelers, charities and donors, dog walkers and dog owners, etc. Several of these markets have been dubbed the 'sharing economy' because people are able to use unused objects or skills better. Most 'sharing economy' platforms are not sharing in the sense learned by kindergarteners: Customers typically pay for the 'shared' services. Horton and Zeckhauser (2016) emphasizes that many of these markets are driven by an unused capacity for durable goods. Low search costs enable such unused capacity to be filled more efficiently.

In a review of the peer-to-peer markets literature, Einav et al. (2016) notes that much of the research takes a market design perspective. For example, Cullen and Farronato (2016) examines an online marketplace that matches buyers and sellers of domestic tasks, such as cleaning, moving, and simple home repair. They emphasize the challenges in growing both the demand and supply sides with respect to variation in the quantity of buyers and sellers over time, economies of scale in matching, and geographic density. A key result is that 
demand fluctuations in this two-sided market lead to changes in quantity supplied rather than changes in prices. Similarly, Hall et al. (2016), Fradkin and Farronato (2016) and Zervas et al. (2016) also show that the responsiveness in quantity supplied to changes in demand conditions is a key aspect of peer-to-peer platforms (specifically, Uber and Airbnb). Low search costs provide market demand information that enables supply to enter the market when needed.

\subsection{Why are digital platform-based businesses so prevalent?}

Platforms are intermediaries that enable exchange between other players. Digitization has led to an increase in the prevalence of platform businesses, even beyond the peer-to-peer platforms discussed above. Most of the major technology firms can be seen as platformbased businesses. For example, Apple provides hardware and software platforms for others to build applications around. Google provides platforms for bringing together advertisers and potential buyers.

As highlighted in Jullien (2012), there are two main reasons digital markets give rise to platforms. First, platforms facilitate matching. In particular, as in the sharing economy platforms, they provide a structure that can take advantage of low search costs to create efficient matches. Often platforms serve as intermediaries between buyers and sellers, as highlighted in Nocke et al. (2007) and Jullien (2012). In the context of a central role of matching, a rich theory literature has arisen that examines competition and pricing strategy in such platform businesses, with an emphasis on the importance of indirect network effects (for example Baye and Morgan (2001a); Caillaud and Jullien (2003); Weyl (2010); Hagiu and Jullien (2011) and, de Corniere (2016)).

Second, platforms increase the efficiency of trade. They do this through lower search costs as well as other aspects of digitization that we discuss below: Low reproduction costs and low verification costs. Hagiu (2012) emphasizes how software platforms enable application 
providers to serve a large number of customers quickly, with the only requirement that the application serve some particular customer need, reproduce at zero cost, and rely on the platform and the other applications to serve other needs. Interoperability is therefore a key aspect of platforms. There is a large literature on the topic, as reviewed in Farrell and Simcoe (2012). A key contribution of this literature is the emphasis on the strategic nature of decisions on interoperability and standards (Rysman and Simcoe, 2008; Simcoe, 2012). A related set of questions examines whether market participants will 'multi-home' and use multiple platforms (Rochet and Tirole, 2003; Rysman, 2007; Halaburda and Yehezkel, 2013).

\subsection{How do low search costs affect the organization of the firm?}

Lucking-Reiley and Spulber (2001) discusses several hypotheses with respect to the impact of the internet on firm structure in terms of the role of online intermediaries and vertical integration. This literature emphasizes information flow generally, in which search is one key type of information flow. Garicano (2000) shows that low-cost digital information flow could increase centralization, by enabling headquarters, and organizational leaders, to understand better what is happening at a distance. On the other hand, Garicano (2000) also shows that low-cost communication could decrease centralization, by enabling front-line employees to access information previously only available to senior employees at headquarters. A variety of papers have explored nuances in this tradeoff within organizations, emphasizing the importance of the particular technology studied.

Bloom et al. (2014) tests this theory directly, using data on European and American manufacturing firms to show that information technology is a centralizing force and communication technology is a decentralizing force. Acemoglu et al. (2007) also discusses the de-

centralizing role of information technology. For example, Forman and van Zeebroeck (2012) shows that digital communication increases in research collaboration across establishments within an organization. Baker and Hubbard (2003) examines the impact of on-board com- 
puters on asset ownership in the trucking industry. They emphasize tracking costs more than search costs and find that aspects of on-board computing that improve monitoring pushed trucking firms to more ownership of trucks while aspects of on-board computing that improve real-time location information pushed trucking firms to less ownership of trucks. Thus, while adoption of digital technology led to improved efficiency, the impact on organization of the firm in equilibrium depends on the nature of the technology and how its specific features affect tradeoffs between competing tensions at the boundary of the firm. McElheran (2014) examines the decision to centralize or delegate IT adoption decisions within firms. Firms with a greater need for integrated processes (digital or otherwise) delegate less. Forman and McElheran (2013) shows that this tendency is mitigated by the ease with which IT enables coordination across firms, so that disintegration of the firm boundary can be seen as an extreme form of delegation.

In addition to the impact on the domestic boundaries of the firm, the reduction in search costs (combined with the reduction in verification costs discussed below) has also led to an increase in international hiring and outsourcing. While international outsourcing is not a new phenomenon (Leamer, 2007), the recent rise of digital international labor market platforms suggests a different avenue for international hiring. Agrawal et al. (2016) shows that online platforms with standardized information disproportionately benefit workers from developing countries. The objective information available online, combined with the ability to send the output of the work (typically information such as data or software code) for free over long distance helps workers who are far from the buyer. Such online labor markets have several important challenges. Using data from online labor markets, Lyons (2017) shows that crosscultural international teams can be less productive because of communication challenges. Relatedly, Ghani et al. (2014) shows that employers in the Indian diaspora are more likely to hire Indians online. 


\section{The Replication Cost of Digital Goods is Zero}

The key shift in the production function is not that digital goods have a marginal cost of zero. Simple microeconomic models with zero marginal cost are not so different from models with positive marginal cost. The demand curve slopes downward and firms price where marginal revenue equals zero.

Instead, a key distinction between goods made of atoms and goods made of bits is that bits are non-rival, meaning that they can be consumed by one person without reducing the amount or quality available to others. A common analogy for non-rival goods is that just as one person can start a fire without diminishing another's fire, information can be shared without diminishing the original information.

In the absence of deliberate legal or technological effort to exclude, bits can be reproduced by anyone-not just the producing firm-at near zero cost without degrading the quality of the initial good. As Shapiro and Varian $(1999$, p. 83) put it, the internet can be seen as a "giant, out of control copying machine."

Nevertheless, the economics of zero marginal cost, non-rival goods can shift things in favor of producers, consumers, or both. In a static model, as marginal costs fall the potential surplus rises and so the welfare impact depends on the final price and associated deadweight loss. The final price and deadweight loss depend on legal and technological tools for exclusion (Cornes and Sandler, 1986), which relate to the ability to track behavior - the subject of the next section. In this section, we emphasize that the underlying technology enables firms and governments to make a choice not to exclude. This can allow individuals to enjoy the full benefits of the non-rival nature of information-based goods.

\subsection{How can non-rival digital goods be priced profitably?}

The non-rival nature of digital goods has led to questions of how to structure pricing of a large variety of non-rival zero-cost goods, should a producer choose to charge. Bundling 
occurs when two or more products are sold together at a single price (Shapiro and Varian, 1998; Choi, 2012). Bundling models have a long history in economics. Stigler (1963) and Adams and Yellen (1976) note that the price discrimination benefit of bundling arises when consumers have negatively correlated preferences. Some people may value an action movie at $\$ 10$ and a romance at $\$ 2$. Others may value the romance at $\$ 10$ and the action movie at $\$ 2$. Selling the bundle at $\$ 12$ yields higher profits than selling the action and romance movies separately. The challenge for firms is to identify such negative correlations in preferences to identify when bundling will increase profits.

Bakos (1999) and Bakos and Brynjolfsson (2000) recognize that, under certain assumptions, this challenge is overcome when many products can be bundled, due to the law of large numbers. Furthermore, the non-rival nature of information goods means that large numbers of information goods can be bundled without substantially increasing costs. Therefore, a simple and useful insight on the economics of non-rival information goods is that it will sometimes be optimal to bundle thousands of digital products together.

Chu et al. (2011) uses an empirical example to show that the intuition of Bakos (1999) applies to relatively small numbers of goods in the bundle. There are also strategic reasons to bundle because it can reduce competition (Carbajo et al., 1990). When bundling has zero marginal cost, such strategic considerations can become particularly relevant (Carlton et al., 2010; Choi, 2012).

Despite the extensive theory work, it is only recently that empirical examples of such massive bundles appeared in the literature, in the form of subscription services for video such as Netflix and music such as Spotify and Apple Music. Aguiar and Waldfogel (2015) shows the Spotify displaces sales but it also displaces 'piracy' or the downloading of music without permission from the copyright holder. They estimate that the reduction in sales and the increase in legal music consumption balance each other so that Spotify appears to be revenue neutral in the 2013-15 time period. 


\subsection{What are the motivations for providing digital public goods?}

Information providers can deliberately decide not to exclude. It is somewhat of a puzzle why private actors would choose to create public goods. Two prominent examples of non-rival public digital goods are open source software and Wikipedia. Both cases involve a deliberate

decision not to exclude, and applying established models is somewhat less straightforward than the bundling models highlighted in the preceding subsection.

Lerner and Tirole (2002) asks why software developers would freely share their code with no direct payment. They emphasize two core benefits from open source that do not appear in standard models of public goods. For individual developers, providing high quality open source code is a way to signal their skills to potential employers. For companies, improving the quality of open source software may allow them to sell other services, that are complementary to open source software (such as hardware or consulting services), at a premium. Underlying these core benefits is the non-rival nature of the code: Digital distribution through the internet means that (high quality) open source contributions can be widely adopted. The literature on the economics of open source that followed has largely supported their hypotheses of career concerns and complementarity (Johnson, 2002; Bitzer and Schroder, 2005; Mustonen, 2005; Lerner et al., 2006; Henkel, 2009; Xu et al., 2016).

Wikipedia represents a different important context for the puzzle of why people contribute to digital public goods. Zhang and Zhu (2011) emphasizes social benefits related to breadth of readership. In the context of Chinese language Wikipedia, they show that users care about audience size, and decrease contributions when part of the audience is blocked due to Chinese government policy. Consistent with this idea of a social benefit, Aaltonen and Seiler (2016) and Kummer et al. (2015) together provide evidence for a virtuous circle in which more editing leads to more views and more views lead to more editing. Contributions are likely related to the interests of the contributors: Wikipedia leaned sharply Democratic 
early on and has gradually become more neutral (Greenstein and Zhu, 2012). Nagaraj (2016) suggests the potential for government sponsorship of digital public goods.

He finds that open mapping information led to a substantial increase in mining activity, particularly for smaller firms with fewer resources. Therefore, open data enabled a wider set of participants to succeed.

More generally, the non-rivalrous nature of digital technology could enable consumers and workers in developing countries to access the same information as people in developed countries, conditional on having access to the internet. In the context of education, Kremer et al. (2013) argues that information technology can improve pedagogy in the developing world. Underlying their argument is an emphasis on non-rival non-excludable digital information, and the public internet-based posting of educational materials. Correspondingly, Acemoglu et al. (2014) emphasizes that digital education will lead to a more equal distribution of educational resources.

There are, however, situations in which welfare may decrease because of a decision not to exclude digital goods from widespread copying. The decision not to exclude non-rival goods can reduce the incentives to produce information goods, a subject we discuss below in the context of copyright policy. It can also create negative externalities. For example, Acquisti and Tucker (2014) shows that policies that mandate 'Open Data' by government may lead to data leakages (or privacy breaches) that affect individuals' welfare offline. Openness, almost by definition, implies a reduction in privacy. Relatedly, Acquisti and Gross (2009) shows that using public data online makes it possible to predict an individual's social security number. This feeds back in general to the idea that while non-excludability may be attractive in principle, it can lead to questions of appropriate data security practices (Gordon and Loeb, 2002; Gal-Or and Ghose, 2005), especially if costly investments in data security also are a public good. 


\subsection{How do digital markets affect copyright policy?}

While digital technology creates public goods, zero marginal cost of production can also create public bads, such as spam (Rao and Reiley, 2012) and online crime (Moore et al., 2009). These have led to policy responses such as the US CANSPAM act. Another example, of digital spam is junk telephone calls, the automation of which has been enabled by digital technologies. Petty (2000) and Varian et al. (2005) evaluate the role of the federally sponsored 'Do Not Call' list in preventing potentially intrusive direct sales calls and find positive effects.

That said, the economics of such bads are relatively straightforward. In contrast, the more challenging policy question for non-rival digital goods is whether the government should intervene through copyright policy to enforce excludability despite the non-rival nature of the goods.

As the internet first diffused in the late 1990s, copyright of music (and text) was often ignored as people freely posted copyrighted goods online. Because of the non-rival nature of digital information, one posted copyrighted item could be useful to millions of people, potentially replacing sales. At the same time, music industry revenue began to fall (Waldfogel, 2012) and this was widely blamed on changes brought by the internet.

Optimal enforcement of copyright has therefore been a key focus of the digital economics literature. The early work focused on the revenue consequences of free online copying. This was referred to as 'file-sharing' to those who believe it should be allowed, and as 'piracy' by those who didn't. The direct effect of free online copying of media is that revenues from the sale of copies of that media fall. At the same time, revenues could rise if the free copies are merely sampled and consumers buy what they like (Peitz and Waelbroeck, 2006). Revenues could also rise for complementary goods like live performances (Mortimer et al., 2012). Finally, revenues could rise if the free copies are limited to developing markets for products with network effects (Takayama, 1994). Empirically, though a small number of 
studies have found positive effects (Oberholzer-Gee and Strumpf, 2007), most studies have found that free online copying reduces revenues in music (Rob and Waldfogel, 2006; Zentner, 2006; Liebowitz, 2008; Waldfogel, 2010), in video (Rob and Waldfogel, 2007; Liebowitz and Zentner, 2012; Danaher et al., 2014; Danaher and Smith, 2014; Reis et al., 2015; Peukert et al., 2017), and in books (Reimers, 2016). This echoes a non-digital historical literature (Li et al., 2015; MacGarvie and Moser, 2015) suggesting a continuity between policy governing digital technologies and earlier policies.

How does copyright affect the creation of new works? This is a more difficult research question as it requires some attempt to measure counterfactual quality and quantity of goods had copyright law not existed (Varian, 2005; Peitz and Waldfogel, 2012; Danaher et al., 2013). Waldfogel (2012) addresses this challenge using two measures of music quality: Historical 'best albums' lists and usage information over time. In both cases, he shows that the quality of music began to decline in the early 1990s and stopped declining after the arrival of free online copying in 1999. Why did quality rise despite declining revenue? He argues that simultaneously with the decline in revenue came a decline in the cost of producing and distributing music. Digitization affected the supply side as well as the demand side, and so quality rose. Results are similar in movies (Waldfogel, 2016) and books (Waldfogel and Reimers, 2015). This contrasts with the economic history literature, which suggested that copyright alone could increase the quality of creative output (Giorcelli and Moser, 2016).

In addition to affecting incentives to innovate, digital challenges to copyright protection may affect incentives to build on prior work. Williams (2013) demonstrates this point in a different intellectual property context and shows that intellectual property protections limit follow-on innovation in gene sequencing. Heald (2009) shows that copyrighted music is less used in the movies than non-copyrighted music. Nagaraj (2017) shows that copyright protection of old sports magazines reduces the quality of Wikipedia pages decades later. This phenomenon is not unique to the digital context. Biasi and Moser (2016) shows that 
eliminating copyright of German books during World War II led to a substantial increase in US scientific output, measured by PhDs in mathematics and patents that cited the German books.

Another challenge for copyright policy driven by the shift in costs of replication is that it has made it easier for other firms to replicate digital content and attempt to aggregate it. This practice has been particularly prevalent in the news media, where policy makers have been encouraged to take action to protect the interest of the newspapers that actually originated this news content. However, in general the work in economics which has evaluated the effect of these aggregators has been to emphasize that such aggregation promotes more exploration rather than necessarily cannibalizing content (Calzada and Gil, 2016; Chiou and Tucker, 2017; Athey et al., 2017).

Overall, copyright law is more important in digital markets because goods can be copied at zero cost. Stricter enforcement of copyright appears to increase revenue to the copyright holder, increase some incentives by potential copyright holders to innovate, but reduce incentives by others to build on copyrighted work. Nevertheless, the literature also shows that, despite ease of copying, digitization has not killed creative industries because production and distribution costs have fallen and because the technology has caught up to facilitate copyright enforcement.

\section{Lower Transportation Costs}

Related to replication being costless, the cost of transporting information stored in bits over the internet is near zero. ${ }^{4}$ Put differently, the cost of distribution for digital goods approaches zero and the difference in the cost of nearby and distant communication approaches zero.

\footnotetext{
${ }^{4}$ While transportation costs could be positive and even high due to network congestion, in practice this has not been an issue. Early on, such network congestion was a key focus of the literature. For example, one of the first volumes on internet economics, Mcknight and Bailey (1998), has several articles on congestion pricing. This early literature on backbone competition and congestion ended up influencing our understanding the economics of net neutrality discussed above (Cremer et al., 2000; Laffont et al., 2001; Besen et al., 2001; Laffont et al., 2003).
} 
In addition, digital purchasing technologies have reduced transportation costs. Consumers buy physical goods online, particularly when offline purchasing is costly or difficult (Goolsbee, 2000; Forman et al., 2009; Brynjolfsson et al., 2009). Furthermore, Pozzi (2013) shows that consumers also use online shopping to overcome the transportation costs of carrying things from the store. In this way, the internet facilitates stockpiling, allowing people to buy in bulk when a discount appears because delivery means there is no need to carry the large quantity of items purchased.

Thus, for information, for digital goods, and for physical goods, transportation costs are lower online.

\subsection{Does distance still matter if transportation costs are near zero?}

Low transportation costs for information mean that the cost of distribution for digital goods approaches zero and that the difference in cost of nearby and distant communication approaches zero.

The potential implications of low transportation costs have been explored in the popular press. Cairncross (1997) suggests that this fall in the costs of transporting information would lead to a "death of distance". Isolated individuals and companies would be able to

plug into the global economy. Rural consumers would benefit by having access to the same set of digital products and services as everyone else. There would be a global diffusion of knowledge. Friedman (2005) identifies several of the same themes in predicting a "flat world" in which businesses anywhere could plug into the global supply chain and produce. Being in the United States would not confer a meaningful advantage relative to India. Both Cairncross and Friedman suggested the potential arrival of a global culture, in which everyone everywhere would consume the same information, an idea with its roots in McLuhan (1964). This idea is implicit in the trade model of Krugman (1979): Countries consume the same goods as transport costs approach zero. Rosenblat and Mobius (2004) formalizes some of 
these ideas in a different context, using network model of collaboration in which long distance collaboration rises but coauthor similarity in other dimensions (such as field of research) also rises.

A less extreme question than "Is distance dead?" is "Does distance matter more or less than it used to?" The most definitive answer to that question comes from Lendle et al. (2016). They compare cross-border sales on Ebay with international trade data. They demonstrate that, while distance predicts both online and offline trade flows, distance matters substantially less on Ebay.

The digital economic literature has emphasized what factors influence the extent to which distance still matters.

As Lemley (2003) notes, "No one is 'in' cyberspace." (p. 523). Therefore, offline options matter. Balasubramanian (1998) examines the importance of offline options using a circular city/Salop (1979) model with the cost of using the direct retailer as constant for all locations, but the cost of using the stores located around the circle depends on transportation costs. The model shows that the benefit of a direct (online) retailer will be largest for those who live far from an offline retailer. Forman et al. (2009) provides evidence to support this model, demonstrating that when a Walmart or Barnes \& Noble opens offline, people substitute away from purchasing books on Amazon. A number of other studies also demonstrate how offline retail affects online purchasing. Related models include Loginova (2001) and Dinlersoz and Pereira (2007) which examine the role of loyalty to the offline store in driving the more price sensitive customers online. Empirically, Brynjolfsson et al. (2009) shows that online sales at a women's clothing retailer are lower from places with many offline women's clothing stores. This impact is driven by the more popular products that are likely to be available in a typical offline store. Choi and Bell (2011) shows that online sales of niche diaper brands are higher in places where they are unlikely to be available offline. Goolsbee (2001), Prince (2007), and Duch-Brown et al. (2017) all show substitution between online and 
offline sales of personal computers. Gentzkow (2007) demonstrates substitution between the online and offline news in Washington DC. Seamans and Zhu (2013), Goldfarb and Tucker (2011a), and Goldfarb and Tucker (2011d) demonstrate substitution between online and offline advertising. Gertner and Stillman (2001) shows how channel conflict interacts with vertical integration and show that vertically integrated apparel retailers went online first. In their review of the literature on online-offline competition, Lieber and Syverson (2012) provides some additional evidence that offline options affect online purchasing. Similarly, in the digital media context, evidence suggests that online media consumption substitutes for, and is replacing, offline media consumption (Wallsten, 2013; Gentzkow, 2007).

In addition to the offline option, the fact that tastes are spatially correlated also matters for the persistent role of distance. Blum and Goldfarb (2006) examines the international internet surfing behavior of about 2600 American internet users, and demonstrate that internet surfing behavior is consistent with the well-established empirical finding in the trade literature that bilateral trade decreases with distance (Overman et al., 2003; Anderson and van Wincoop, 2004; Disdier and Head, 2008). In other words, even for a product with zero shipping costs (visiting websites), people are more likely to visit websites from nearby countries than from faraway countries. This relationship between distance and website visits is much higher in taste dependent categories (and loses statistical significance in the non-taste dependent categories). Distance matters because it proxies for taste similarity. Alaveras and Martens (2015) replicates this core result using much richer data on website visits by users in a large number of countries. Sinai and Waldfogel (2004) also shows that highly populated areas produce more content, and that because tastes are spatially correlated in the sense that people are more likely to consume local media than distant media, people in highly populated areas are particularly likely to go online. This geographically specific nature of tastes is also reflected in the consumption of digital goods such as music (Ferreira and Waldfogel, 2013) and content (Gandal, 2006). Quan and Williams (2017) demonstrates 
that accounting for spatial correlation in tastes reduces the estimated consumer surplus from increased online variety by 30 percent.

In addition to offline choices and spatially correlated tastes, another factor which explains the continuing role of distance is the presence of social networks. Much online behavior is social, and social networks are highly local (Hampton and Wellman, 2003). Thus, while zero transportation costs of information mean that you can communicate with anyone anywhere in the world for the same price, the vast majority of most people's email comes from those who either live at the same home or work in the same building. Gaspar and Glaeser (1998) speculates that because of the spatial correlation of social networks, the internet may be a complement to cities. More efficient communication would be especially important for those who communicate frequently. In other words, though the relative costs of communication fall more for distant communication, the overall importance of local communication might mean that cities benefit most.

Agrawal and Goldfarb (2008) provides some evidence in support of this hypothesis by showing that as new universities connected to a 1980s internet-like network, they increased their collaboration rate with those already connected. The biggest change in collaboration rates were for co-located universities in different quality tiers. The paper emphasizes the likely local social networks of researchers in the same city. Looking at online 'crowdfunding' of music, Agrawal et al. (2015) provides further evidence of the importance of local social networks by showing that musicians' early funding tends to come from local supporters who the musicians knew prior to joining the crowdfunding platform. As the musician gains prominence on the website, the later funding often comes from distant strangers.

Finally, in the absence of the improvements in verification discussed below, trust is easier locally. Hortacsu et al. (2009) shows that same-city sales on Ebay and MercadoLibre (a Brazilian electronic commerce platform) are disproportionately high, likely because some products are observed and delivered in person. Furthermore, Forman et al. (2009) shows 
that Americans follow the online product recommendations of others who live near them.

\subsection{Can policy constrained by geographic boundaries shape digital behavior?}

Early work worried that the internet could undermine local regulation and national sovereignty (Castells, 2001). Some research is consistent with this idea: Online sales have been higher where the difference between online and offline tax rates is highest (Goolsbee, 2000; Ellison and Ellison, 2009b; Anderson et al., 2010; Einav et al., 2014). When local regulation prohibits offline advertising, similar online advertising is more expensive (Goldfarb and Tucker, 2011d) and more effective (Goldfarb and Tucker, 2011a). This substitution suggests that online and offline markets should be considered together in the context of antitrust (Goldfarb and Tucker, 2011e; Brand et al., 2014).

At the same time, regulation can mean that users experience the internet differently in different locations. At the extreme, regulation can prohibit certain content, making the experience of using the internet different across locations. Zhang and Zhu (2011) examines the impact of the blocking of Wikipedia in China in October 2005 on the motivations of others outside China to contribute. Thus, a key online website was available in some places and not others. More generally, some countries regularly block access to certain websites changing the nature of the internet across locations.

Regulation can also change what users find available across locations. Copyright policy leads to variation in the availability and consumption of media across locations (GomezHerrera et al., 2014; Chiou and Tucker, 2017; Athey et al., 2017; Calzada and Gil, 2016). Privacy policy leads to different advertising and different website success (Goldfarb and Tucker, 2011f; Tucker, 2015). Trademark policy leads to different search experiences (Chiou and Tucker, 2012; Bechtold and Tucker, 2014).

Thus, when regulation does not reach into the online sphere, the zero transportation costs of information in the online channel generate a disproportionate benefit of online information 
in regulated contexts. However, when regulation does reach the online sphere, it can have a substantial impact on the nature of the internet across locations.

\section{$5 \quad$ Lower Tracking Costs}

The first three drops in costs, those associated with search, replication, and distance, were well discussed in the early digital economics literature. However, the importance of the lowering of the next two costs we discuss, tracking and verification, has only become clear in the last decade.

Digital activity is easily recorded and stored. In fact, the technology typically stores all information automatically, and firms and consumers have to make a deliberate decision to discard data. Reductions in tracking costs enable personalization and the creation of one-to-one markets, leading to renewed interest in established economic models with asymmetric information and differentiated products such as price discrimination, auctions, and advertising models.

\subsection{Do lower tracking costs enable novel forms of price discrimination?}

The ability to use digital technologies to track individuals enables personalized markets. Several economists recognized this potential for digital price discrimination as the internet commercialized in the late 1990s (Shapiro and Varian, 1998; Smith et al., 2001; Bakos, 2001). Even first-degree price discrimination seemed like it might become more than a theoretical curiosity.

One form of price discrimination that has received a great deal of attention in the theory literature on digital markets is behavioral price discrimination (see Fudenberg and VillasBoas (2012) and Fudenberg and Villas-Boas (2007) for reviews). This literature emphasizes that the low cost of collecting digital information makes it easier for companies to pricediscriminate based on an individual's past behavior. The research builds on a large price discrimination literature that does not specifically emphasize digital markets (Hart and Ti- 
role, 1988; Chen, 1997; Fudenberg and Tirole, 2000). Broadly, the research explores the benefits and costs of identifying previous customers for monopolies (Villas-Boas, 2004) and competing firms (Shin and Sudhir, 2010; Chen and Zhang, 2011). Fudenberg and Villas-Boas (2012) summarize this literature to conclude that under monopoly, firms benefit from the additional information but under competition the information may increase the intensity of competition. Furthermore, the benefits of the information to a monopoly may lead consumers to strategically withhold information. In other words, consumers become privacy-sensitive (Taylor, 2004; Acquisti and Varian, 2005; Hermalin and Katz, 2006). In the opposite direction, rules that restrict the flow of information hurt firms' ability to price-discriminate and therefore may leave some consumers unwilling to buy at the offered prices (Taylor and Wagman, 2014; Kim and Wagman, 2015).

Another form of price discrimination that has received attention in the digital economics literature is versioning. Bhargava and Choudhary (2008) provide a model of versioning when variable costs are zero. Fay and Xie (2008) explore versioning based on probabilistic selling. For example, airlines and hotels offer low price versions of their products on Priceline.com, in which there is buyer uncertainty about the specific product being bought.

Empirical support for digital price discrimination is limited, despite the rich theoretical discussion of the potential for personalized pricing. For example, versioning is a basic form of third-degree price discrimination that precedes most digital markets (Maskin and Riley, 1984; Deneckere and McAfee, 1996; Corts, 1998; Fudenberg and Tirole, 1998). Rao (2015) provides experimental support for the value of versioning digital products, demonstrating that online limited time 'rentals' can increase profits by segmenting high and low value consumers. Despite the ease of even this most straightforward form of price discrimination, Shiller and Waldfogel (2011) argue digital firms may not be versioning, or more generally price-discriminating, as much as would be optimal. In particular, they puzzle over the surprisingly uniform nature of pricing for digital music. They argue that uniform pricing 
of music appears to lead to lower-than-optimal profits for firms, but do not provide a clear answer to this puzzle. While there is evidence of broad versioning of online media (Chiou and Tucker, 2013; Lambrecht and Misra, 2017), the theoretical literature on digital price discrimination seems to be ahead of the empirical work and of firm practices. While there is evidence of first degree price discrimination in higher education (Waldfogel, 2015), the only online research example we found is Dube and Misra (2017), who demonstrate the feasibility and profitability of targeting many prices to different customers of an online service based on a large number of characteristics.

\subsection{Why has there been a shift from personalized pricing to personalized ad- vertising?}

Given the emphasis of the theoretical literature on the ease and practicality of behavioral price discrimination and the potential for personalized pricing of goods online, it is perhaps a surprise that for many of these goods consumers face a price of zero (Evans, 2009). Thus, perhaps the most striking effect of the creation of low online tracking costs has not been to use personalized profiles to charge different consumers different prices, but instead to show these different consumers more appropriate, relevant, and profitable advertising.

Variants of these ideas appear in a rich theory literature on two-sided markets, emphasizing the digital context (Baye and Morgan, 2001b; Anderson and de Palma, 2009, 2013; White, 2013; Athey et al., 2014). Baye and Morgan (2001b) demonstrates that an information intermediary will price low to consumers, while charging advertisers a high enough price that some choose not to participate. Anderson and de Palma (2009) and Athey et al. (2014) each model consumer attention as scarce and explore advertiser competition for that attention. Athey et al. (2014) emphasizes that if an advertiser wants to send a message to a customer offline, they need to rely on noisy signals based on media demographics. In contrast, online targeting technology is such that an advertisers can target a particular consumer. In the 
presence of multiple media outlets and multi-homing by consumers, the equilibrium outcome is that online advertising prices can be much lower than offline advertising prices even though the online advertising is in fact more useful to the advertiser. However, Gentzkow (2014) argues that the price of attention is not lower online than offline, which challenges this prediction.

Perhaps because of these forces, many of the largest online companies-in terms of revenues, profits, and users-are advertising-supported. Low-cost tracking means that what distinguishes online advertising from offline advertising is that it is targeted (Goldfarb and Tucker, 2011b; Goldfarb, 2014). This difference is highlighted in models that explore competition between online and offline advertising (Athey and Gans, 2010; Bergemann and Bonatti, 2011; Johnson, 2013). Athey et al. (2014) and Levin and Milgrom (2010) use very different models to demonstrate that better targeting may not help online media. Athey et al. (2014) show that improved tracking can increase competition between media outlets. Levin and Milgrom (2010) show that too much targeting can lead to insufficient competition among advertisers for the user attention sold by a monopolist media firm.

This better targeting has led to a thriving literature that measures advertising effectiveness. Because ad messages are sent to individuals in bits (rather than broadcast through billboards and newspapers), it is relatively easy to identify consumers that see ads, to randomize which consumers see ads, and even to track those consumers through purchase. Until recently, this was very difficult and so there were few well-identified studies of advertising effectiveness. Low tracking costs make it relatively easy to run field experiments online, and large scale field experiments have been the focus on the recent literature.

Research on online advertising effectiveness has been largely conducted by research economists working with industry. For example, Lewis and Reiley (2014) uses a field experiment on 1.6 million Yahoo customers that connects online advertising to offline department store sales. They find that online advertising increases offline sales in a department store. 
Blake et al. (2015) shows that in many cases search engine advertising-the key revenue generator for Google-does not work. In particular, they demonstrate with a large field experiment at Ebay that consumers will often click on the 'organic' link anyway and navigate to the advertiser's page. They argue that much search engine advertising is wasted. Simonov et al. (2017) uses data from Microsoft's Bing search engine to show that the results for Ebay may be driven by the strength of Ebay as a particularly well-known brand. Less well-known advertisers seem to benefit from search advertising.

While much better than prior ways to measure advertising effectiveness, there are still substantial challenges. Correlational research, even with detailed data, typically yields inaccurate measures of advertising effects because the signal-to-noise ratio for advertising's effect on sales is low (Lewis et al., 2015; Gordon et al., 2016). Furthermore, even with experiments, advertising effects are subtle relative to the variance in purchase behavior and so studies need to be highly powered (Lewis and Rao, 2015).

A large literature also emphasizes the role of targeting as a distinct and important feature of online advertising. Goldfarb and Tucker (2011c) shows that targeted banner advertising is effective, but only as long as it does not take over the screen too much. Targeting works when subtle, in the sense that it has the biggest impact on plain banner ads, relative to how it increases the effectiveness of other types of ads. Lambrecht and Tucker (2013) and Tucker (2012b) demonstrate the effectiveness of other types of online advertising targeting.

As noted above, online media support their business by selling scarce consumer attention to advertisers. New technologies are emerging that allow consumers to block advertising online. Such ad blocking may reduce revenues and, perhaps counterintuitively, increase the quantity of ads shown to those without ad blockers (Anderson and Gans, 2011). In a test of these ideas, Shiller and Waldfogel (2017) uses data on ad blocking and website visits to show that widespread use of ad blockers may decrease the quality of websites on the advertising-supported internet. 


\subsection{Why are online goods and services often sold by auction?}

The rise of online advertising, along with individual-level tracking technologies, has created a difficult pricing problem: How can a firm choose prices for thousands of advertisements that might be priced differentially to millions or even billions of customers? As economists have long-recognized, auctions are a particularly useful tool for price discovery. Consequently, digital markets typically use auctions to determine prices for advertising. Auctions are also used to price some other goods.

Originally, advertising on Yahoo!'s search page in the 1990s was priced according to a standard rate. Goto.com's insight-that an auction could leverage the fact that the value of advertising depended on the search term-led to a new way to price discriminate in advertising. Rather than price for the search page, price could be at the level of the search term. Google and Bing's ad auctions run on this insight. A large literature has arisen to develop auction formats for this context (Varian, 2007; Edelman et al., 2007; Levin and Milgrom, 2010; Arnosti et al., 2016). Today, advertising auctions, particularly for display advertising, often take into account addition information provided by online tracking technologies, such as websites visited in the past and products observed.

Less related to tracking costs, online auctions have also been used for price discovery for goods, most notably on Ebay. An early review of the auction literature is provided in Ockenfels et al. (2006). They emphasize that the transactions costs of conducting and participating in auctions are lower in the digital context. Furthermore, many digital goods are not standardized in the sense that buyer valuations vary over time and location, and so the price discovery function of the auction is particularly useful. This idea also appears in Varian (2010) which describes the benefits of computer-mediated transactions with respect

to decentralized price discovery, and therefore more finely based price discrimination. While auctions for goods (rather than advertising) still exist online, Einav et al. (2017) shows 
that goods auctions are in decline as online markets have matured. The prominent role of auctions in economic theory means that a separate literature has used the digital setting as a context to test long-established theory. This research, pioneered by Lucking-Reiley (1999), is not about digital markets per se, but uses the digital context to inform a broader theory literature (Roth and Ockenfels, 2002; Bajari and Hortacsu, 2003; Einav et al., 2016).

\subsection{How do digital markets affect privacy policy?}

Low tracking costs have led to a renewed interest in the economics of privacy, as highlighted by a recent review in this journal (Acquisti et al., 2016).

In general the economics literature on privacy, both offline and online, grapples with the question of how privacy should be treated in terms of the consumers' utility function. Should economists treat privacy as an intermediate good, that is a good whose value simply lies in the way it can moderate the achievement of another good, or as a final good, that is, a good that should be enjoyed and valued for its own sake (Farrell, 2012)? Much policymaking is grounded on the idea that privacy is a final good where a distaste for others intruding on or gathering knowledge about an individual's personal domain is valid as a driver of an individual's utility. However, much the theoretical literature analyzes privacy as an intermediate good, because of the implications for personalized pricing that are discussed above (Taylor, 2004; Acquisti and Varian, 2005; Hermalin and Katz, 2006).

Privacy regulation can affect the nature and distribution of economic outcomes (Goldfarb and Tucker, 2012a). (Edelman, 2009) and (Lenard and Rubin, 2009) emphasize that there is a trade-off between the use of online customer data to subsidize zero-price goods and advertising performance. Goldfarb and Tucker (2011f) show that European privacy regula-

tion that restricted online tracking led to a substantial decline in the effectiveness of online advertising in Europe. Johnson (2014) estimates the financial effect of privacy policies on the online display ad industry, suggesting an opt-in policy or a tracking ban would reduce 
welfare substantially, though an opt-out policy would have little effect. Johnson's paper is very useful for understanding the effect on publishers (rather than advertisers) of privacy regulation.

Kim and Wagman (2015) shows that regulation of sharing financial information increased defaults on loans during the financial crisis. Miller and Tucker (2009, 2011) show that US healthcare privacy regulation reduced hospital adoption of electronic medical records, leading to worse health outcomes. On a more positive note in favor of privacy, Tucker (2014) shows that firm-implemented privacy controls designed to encourage con-sumers' perceptions of control can actually enhance the performance of online advertising. Tucker (2012a) compares this result with work that suggests there may be benefits from addressing consumer privacy concerns, building on research that illustrates how perceptions of control influence privacy concerns in general (Brandimarte et al., 2012).

In general, the precise nature of privacy protection can be expected to matter a lot for the direction of innovation: It is not a matter of a simple binary choice to have privacy protection or not. This is emphasized in Miller and Tucker (2014), which shows that different types of privacy protections had very different effects on the adoption of personalized medicine technologies: Regulations that gave consumers control over disclosures enhanced adoption, but regulations that imposed consent requirements decreased adoption.

Privacy regulation puts a cost on tracking information flows. The welfare effects of these costs may be ambiguous.

First, there may be knock-on effects to industry structure from privacy regulation. Campbell et al. (2015) shows that because privacy regulations typically require firms to persuade their consumers to give consent, which in turn imposes a cost on the consumer, small firms and new firms are disproportionately affected, because it is harder for them to obtain consent under the regulation.

Second, welfare complications of privacy policies are also hard to assess due to a privacy 
paradox, where consumers state an affinity for privacy, but then act in ways which is not consistent with this stated preference. Athey et al. (2017) provides some evidence about the extent to which small incentives, distracting information, and small navigation costs can lead to a gap between stated privacy preferences and actual behavior. Furthermore, assessing the value of privacy is complicated for many reasons, including that privacy preferences for the same individual change over time Goldfarb and Tucker (2012b).

Third, much of the work in the economics of privacy has understandably focused on questions relating to industrial organization, there are also implications of digital technologies and privacy for the economics of national security. In addition to improving the ability of firms to track consumers, digital technology allows government crime-fighting agencies to track a broad swathe of the population. Marthews and Tucker (2014) shows that increasing consumer awareness of government data use leads to increased privacy-protecting behavior among consumers in their interactions with firms.

\section{Reduction in Verification Costs}

The reduction in tracking costs has also led to a reduction in costs associated with the verification of identity and reputation. This was not anticipated by the early literature in economics because earliest reporting on the internet suggested that it would be a vehicle for anonymity - "On the Internet, nobody knows you're a dog." ${ }^{5}$ Furthermore, in addition to tracking cost falling, digital technologies have also made it easier to verify identity and also create a digital reputation.

In the absence of such technologies, a long-standing solution for firms to provide credible information about quality was to develop a reputation in the form of a brand (Tadelis, 1999; Smith and Brynjolfsson, 2001; Waldfogel and Chen, 2006). However, digital markets involve thousands of small players. Furthermore, these small players can be unfamiliar to potential

\footnotetext{
${ }^{5}$ The New Yorker on July 5, 1993
} 
customers. Einav et al. (2017) estimates the $88 \%$ of online Visa transactions are with a merchant that the customer does not visit offline. Alternative mechanisms to brand-based reputations are needed. The literature on verification costs builds on economic models of reputation, exploring when the experiences of previous buyers and sellers can enable market exchange in the presence of asymmetric information about quality and trustworthiness. This emphasis on reputation models distinguishes the literature on verification costs from the literature on tracking costs, with emphasizes price discrimination, advertisement targeting, and other forms of personalization.

\subsection{How do online reputation systems facilitate trust?}

The most common such mechanism is an online rating systems in which ratings from past buyers and sellers are posted for future market participants to see. The marketplace that has received the most attention in the literature is Ebay. As mentioned above, one reason Ebay has received so much attention by economists is that it provided a useful setting to test auction theory. Another reason relates to reputation mechanisms. Ebay recognized the challenges of getting people to buy from strangers who they will not meet in person (Resnick and Zeckhauser, 2002; Livingston, 2005). To address this issue, they built, and continually adapted and improved, a ratings system. The effectiveness and development of this ratings system has been the subject of hundreds of papers in economics and management. For example, Ba and Pavlou (2002) shows how a ratings system can enable trust in the absence of repeated interactions. A number of papers empirically demonstrate that better-rated sellers have higher prices and higher revenues (Melnik and Alm, 2002; Livingston, 2005; Houser and Wooders, 2005; Lucking-Reiley et al., 2007). Cabral and Hortacsu (2010) demonstrates differences between positive and negative feedback, emphasizing how the ratings system acts as a disciplining force in the marketplace in which sellers with low ratings exit from Ebay's platform. 
Therefore, the original emphasis of the reputation literature was as a platform for overcoming trust in long-distance transactions. Dellarocas (2003) recognizes early on that the application of these feedback mechanisms was not limited to online exchange. Instead, Dellarocas argued that such mechanisms would enable a variety of market activities, both online and offline. As long as incentives to deviate are not too high, such systems can provide credible quality signals in a variety of settings (Dellarocas, 2003; Cabral, 2012).

One key application is to provide information on product quality. Rather than enhance information about a particular seller, ratings can inform consumers about the best products available within a platform. It might be in the platform's interest to provide such information so that consumers are directed to the highest quality products. Comparing changes in reviews on Amazon relative to Barnes \& Noble, Chevalier and Mayzlin (2006) demonstrates that positive reviews lead to higher sales.

More recently, the literature has focused on how online tools reduce verification costs in offline settings. Luca (2011) shows how online restaurant reviews on Yelp impact restaurant demand, particularly for independent restaurants. Overall, his results suggest that Yelp led to a decrease in the share of chain restaurants relative to independents. Hollenbeck (2016) finds a similar result for hotels.

It is easier to establish an online reputation using online reputation mechanisms, but the mechanisms for damaging that reputation in the form of consumer complaints have also become easier. Historically, complaints were registered with letters, and then calls into call centers. Social media enables rapid widespread communication of complaints to both the firm and a wider audience. Gans et al. (2016) uses data from Twitter to explore ideas on the relationship between market power and consumer voice first sketched out in Hirschman (1970). They show that consumers are more likely to voice their complaints via Twitter in locations where airlines have a higher share of flights. In turn, airlines are more likely to respond to consumers in these markets. Tucker and Yu (2017) shows some positive effects 
of digital technologies, in that the use of mobile apps to receive complaints can actually advantage less educated consumers who are more likely to suffer from employee-consumer discrimination in the treatment of their complaints.

A benefit of improved verification procedures online for individuals has been the ability to more securely and easily make payments. This is demonstrated by Economides and Jeziorski (2017), which shows the power of using mobile devices to digitally verify identity in Tanzania. They show that this power enables the use of mobile payments networks to transfer money to others, but also, equally importantly, to transport money over short distances. People appear to deposit cash after work, walk home, and then pick up the cash at home. The verification system enables easy deposits and withdrawals, thereby reducing the risk of robbery. Digital verification, in the form of DNA databases, has also been shown to reduce crime (Doleac, 2017).

As technology improves, verification may continue to become easier. Researchers have speculated that the blockchain is a promising technology for reducing verification costs further (Catalini and Gans, 2016). Currently most of the literature on blockchain technologies focuses on specific applications of the technology such as cryptocurrencies (Böhme et al., 2015; Catalini and Tucker, 2016). However, if blockchain technologies achieve the promise highlighted in Catalini and Gans (2016), then we might see a diverse literature emerge over the next few years on the consequences of low-cost verification across a variety of empirical setting.

\subsection{Is there a role for policy in reducing reputation system failures?}

Given the important role of such systems in generating demand, it is perhaps unsurprising that the economics literature has focused on questioning when reputation systems fail. Often the failures relate to incomplete ability to verify the person doing the rating online. One type of failure relates to a selection bias: Not all consumers provide ratings. Nosko and Tadelis 
(2017) shows evidence of such a selection bias, in which buyers with a bad experience do not bother to rate the seller. They instead stop buying from any sellers on the platform into the future. Poor service by a seller therefore creates an externality. The failure of the reputation systems hurts the platform rather than the individual seller. Another type of failure relates to direct manipulation of the ratings by the firms or their competitors. Mayzlin et al. (2014) and Luca and Zervas (2016) show evidence of manipulation, in which firms seem to give themselves high ratings while giving low ratings to their competitors. This evidence of manipulation suggests that ratings systems alone are insufficient.

The challenges of ratings systems were recognized relatively early in the digital economics literature. Consider the market for collectible baseball cards. When buyer and seller are in the same place, the buyer can inspect the quality of the card in the store. They can look for rips, folds, or frayed edges. Online, quality is hard to assess. Jin and Kato (2006) provides evidence of fraud in these markets. They show that the online reputation system is insufficient in many ways. In a companion paper (Jin and Kato, 2007), they show how a professional grading industry grew to help solve the information asymmetry between buyers and sellers online. Stanton and Thomas (2016) shows the value of online intermediaries in providing information beyond platform ratings by examining worker and firm behavior on an online labor market. They show that new workers benefit from affiliating themselves with an agency.

The platforms also work to improve their reputation systems. Fradkin et al. (2017) documents two experiments made at Airbnb to improve their reputation system: Offering monetary incentives to submit reviews and implementing a simultaneous review process to reduce strategic reciprocity. Hui et al. (2016) shows, in the context of Ebay, that platforms benefit by having both reputation systems and regulations to expel bad actors.

In each of these cases, it has been the private sector that has reduced these reputation system failures. To the extent that there has been a role for policy, it has been in the 
enforcement of contracts and prevention of fraud. At this point, the literature does not point to a specific digital policy with respect to reputation systems failures.

One aspect of policy related to verification is the nature of intellectual property tools such as trademarks. Trademarks allow customers to verify whether a brand is indeed the brand it claims to be. Chiou and Tucker (2012) and Bechtold and Tucker (2014) document that, online, consumers use trademarks to search pro-actively. The trademark therefore serves two purposes: It verifies identity and it provides a path to search for related products. Trademark policy needs to be narrow enough to facilitate search related to trademarks, but broad enough to ensure that such search does not sow confusion on brand identity.

\subsection{How do digital markets affect anti-discrimination policy?}

A second policy issue driven by changes in verification relates to discrimination. If people were indeed truly anonymous on the internet then there could be no direct discrimination. However, the drop in verification costs and the ability to identify an individual and also their characteristics makes discrimination possible (and potentially low cost) in a digital environment.

The question then for policy makers is whether there is something unique to the online setting which requires additional regulation beyond existing anti-discrimination law. One area this is hotly debated is in the use of algorithms to parse data and automate the allocation of resources and decision making. This is investigated in Lambrecht and Tucker (2016), which shows that algorithms may lead to apparently discriminatory outcomes for innocent reasons. In particular, they show that ads for STEM education are disproportionately shown to men by online algorithms because advertising to men is less expensive overall than advertising to women, and so advertisers who are indifferent to gender end up showing their ads to men more often.

Broadly, on the one hand, while tracking is easier, such tracking may focus on dimensions 
that are legally and morally less controversial, such as preferences rather than race. If digital transactions mean that gender and race information is not revealed, then discrimination may fall. Morton et al. (2003) shows that internet car purchasing reduces gender- and race-based price discrimination. Cullen and Pakzad-Hurson (2017) shows that a reduction of privacy of wages in online platforms decreases pay differences across workers (though it also reduces average pay).

On the other hand, if gender or race or other sensitive information are revealed, it is possible that, in the absence of other information, discrimination is high. For example, Ayres et al. (2015) and Doleac and Stein (2013) show that sellers receive lower prices when

a black hand is shown with the item than when a white hand is shown. Acquisti and Fong (2013) presents the results of a field experiment to study how employers use information on social networks to filter the suitability of employees. They find considerable use of social networking sites for potentially discriminatory purposes. Similar results have been found in a variety of other online contexts (Pope and Sydnor, 2011; Edelman and Luca, 2014).

Both online and offline, discrimination is prevalent. Open questions remain as to whether discrimination is more prevalent online or offline, and as to whether policies aimed at reducing online discrimination specifically will reduce discrimination overall, or simply push discrimination into another setting.

\section{Consequences of Digitization for Economic Actors}

As people spend more time consuming digital media and buying products online, and as business and government increasingly use digital technology, it suggests a broader question: How does storing information in bits rather than atoms affect welfare? As search, reproduction, transportation, tracking, and verification costs fall, has that had an effect on the economy?

Broadly, the literature has tackled this question in four different ways: Country-level 
effects, region-level effects, firm-level effects, and consumer-level effects.

\subsection{Country-level effects}

The macroeconomic productivity literature with respect to internet technology has its roots in the Solow (1987) claims that "you can see the computer age everywhere but in the productivity statistics." This productivity puzzle persisted for many years. A large growth accounting literature has arisen to examine this 'productivity puzzle' and measure the overall impact of digital technologies on the economy. While we view this literature as beyond the scope of this article, Jorgenson et al. (2008) and Van Reenen et al. (2010) both summarize it to suggest that there was a post-1995 productivity surge that was largely driven by digital technology investment and usage.

Still, measuring the productivity shifts is difficult. Haltiwanger and Jarmin (2000) lays out several of the anticipated challenges in measuring the effect of the digital economy: Service industry output, data on digital technology spending, price deflators, etc. A key challenge relates to intangible capital (Corrado and Hulten, 2010) which has been found to affect productivity measurement in both the United States and the United Kingdom (Corrado et al., 2009; Marrano et al., 2009). Soloveichik (2010) takes on this measurement challenge and identifies about 65 billion dollars in intangible capital related to books, movies, music, and television.

A different stream of work on country-level effects examines how digital communication may affect trade flows for digital and physical goods. Freund and Weinhold (2004) provides suggestive evidence that the internet increased trade in physical goods due to a reduction in the cost of international communication. The asynchronous nature of email communication may be particularly important for reducing the cost of communication across many time zones (Borenstein and Saloner, 2001). Gomez-Herrera et al. (2014) suggests, however, that this increase may disproportionately benefit English-language countries. Several of the 
papers highlighted earlier in this review demonstrate that the internet facilitated trade in digital services (Blum and Goldfarb, 2006; Alaveras and Martens, 2015; Lendle et al., 2016), and this might lead to offshoring of certain jobs (Tambe and Hitt, 2012). While there is some debate about whether distance matters less overall than it did prior to the diffusion of the internet (Leamer, 2007; Cristea, 2011; Krautheim, 2012), our reading of the literature is that those papers that focus on the direct impact of the internet find a decrease in the role of

distance in trade (Freund and Weinhold, 2004; Clarke, 2008; Lendle et al., 2016; Hui, 2017) while other papers identify other weaker forces moving in the opposite direction. Consistent with an impact of easy international communication on trade, Gorodnichenko and Talavera (2017) shows that exchange rate pass-through is faster online.

\subsection{Region-level effects}

Another question is the extent to which the internet has led to redistribution of economic benefits within countries and in particular between cities and rural areas. Gaspar and Glaeser (1998) notes that digital communication could be a substitute or a complement to cities. Overall, the literature suggests that the biggest beneficiaries of digital technologies and data have been in large urban areas. The prime early beneficiaries of online media were in urban areas because the highest quality online content was produced in urban areas. This might be one reason why Savage and Waldman (2009) finds that urbanites have higher willingness to pay for broadband. Eichengreen et al. (2016) shows that efficient electronic communication in foreign exchange markets led to an increase in offshore currency trading and the consequent agglomeration of currency markets in London and a small number of other major financial centers. Forman et al. (2012) shows that wealthy cities were the primary beneficiaries of the business internet.

The mechanism through which cities appear to have benefited has been shown to depend on agglomeration effects, particularly with respect to skilled workers in local labor markets. 
Forman et al. $(2005,2008)$ show that internet adoption by businesses is higher in cities and in large companies but the advantage associated with being in a city or a large company are substitutes for each other. This indicates the importance of agglomeration effects. Dranove et al. (2014) finds similar results for hospitals.

In contrast to the above work, there is some evidence that internet adoption has some benefits for isolated individuals and rural areas. Autor (2001) and Gaspar and Glaeser (1998) speculated that the internet might reduce the need for task-specific workspace, thereby increasing the prevalence of 'telecommuting' and reducing the need for home and work to be nearby. Kolko (2012) shows that broadband disproportionately benefited people in low density areas in terms of employment, though the overall effect is small. Furthermore, while the primary result in the Sinai and Waldfogel (2004) study cited above is that urban areas have higher quality internet content, they also show that isolated individuals consume disproportionately more internet news. For example, blacks in white neighborhoods consume more internet news. Finally, Forman et al. (2005) shows that basic internet technologies have (perhaps disproportionately) benefited rural and isolated cities.

Overall, two forces are at play. Agglomeration effects mean that cities disproportionately benefit. Low cost communication, however, can benefit the geographically isolated. In any particular context, the overall result depends on the balance between these forces. Generally, the more difficult the technology is to use, the more likely that agglomeration effects dominate.

\subsection{Firm-level effects}

As noted above, the growth accounting literature has suggested a compelling link between digital technology investments and productivity growth at the country level; however, causal inference is difficult with macro-level measurement. There is a large and growing literature that documents a direct link from digital technology adoption and usage to productivity 
growth at the firm level. By using micro data and various econometric techniques to address selection, omitted variables bias, and simultaneity, this literature has found that digital technology adoption and usage does enhance productivity. However, the story is not as simple as it seems at first. Only some types of firms experience improved productivity. Various factors enhance or mitigate this relationship, including organizational change, skills, geography, regulation, firm size and age, and the potential for spillovers and/or network externalities.

Reviews by Brynjolfsson and Saunders (2010) and Draca et al. (2006) conclude that ICT adoption and usage increase firm performance. This conclusion is driven by a large number of papers and a variety of settings. The correlation between IT and productivity is even stronger when ICT investment is modeled with a lag (Brynjolfsson and Hitt, 2003).

There are also specific case studies on the effects of ICT on productivity. Baker and Hubbard (2004) show that ICT improved productivity in trucking. McElheran and Jin (2017) show improved productivity in manufacturing. Agrawal and Goldfarb (2008) show that BITNET increased academic productivity at middle-tier universities. In healthcare, Athey and Stern (2002) show that ICT, in the form of Enhanced 911, improved emergency response, Miller and Tucker (2011) and McCullough et al. (2016) show that Electronic Medical Records improve patient outcomes, Dranove et al. (2014) show that EMR reduces hospital costs in the presence of complementary skills but not otherwise, and Lee et al. (2013) show that electronic medical records (EMR) increase hospital productivity.

Bloom et al. (2012) use a large-scale multi-country firm-level panel database on ICT and productivity. Their database contains 19,000 firms in $13 \mathrm{EU}$ countries over 11 years, plus a smaller panel of US firms over the same time period. They conclude that ICT does increase productivity, though they find considerable heterogeneity in this effect across countries and type of firm. They emphasize the importance of organizational capital, showing that US multinationals operating in the UK experienced the same productivity miracle as 
US-based establishments. In contrast, other multinationals (and other firms) in the UK did not. The title communicates the idea well: Americans do I.T. better. They argue that US firms are organized in way that allows them to use ICT more efficiently. This essential role of organizational capital and organizational structure in making productive use of ICT investments is a recurring theme elsewhere in the literature (Bresnahan et al., 2002; Brynjolfsson and Saunders, 2010; Garicano, 2010; Tambe et al., 2012; Brynjolfsson and McElheran, 2016).

In addition to change in the organizational structure, the most effective use of advanced ICT also involves 'co-invention', the process of adapting ICT to the organization's needs (Bresnahan and Greenstein, 1996). Such process innovation is easiest for firms in places that have a pool of local ICT expertise to draw on (Forman et al., 2008; Dranove et al., 2014). This of course reflects the extensive literature on skill-biased technological change, which is long and beyond the scope of this review. As reviewed in Acemoglu and Autor (2012), given that prior generations of IT are skill-biased, it is perhaps unsurprising that use of the internet to enhance productivity is also skill-biased. Correspondingly, in the context of the internet, Akerman et al. (2015) provide evidence that broadband diffusion in Norway disproportionately benefited skilled workers.

\subsection{Consumer-level effects}

Measurements that focus on productivity or national income accounts do not measure consumer surplus. To the extent that much of the most valuable content online is free, measures of productivity and GDP may miss a potential increase in consumer surplus driven by the internet (Scott and Varian, 2015; Brynjolfsson et al., 2017; Greenstein and McDevitt, 2011; Goolsbee and Klenow, 2006). With time use data, Wallsten (2013) demonstrates that we are spending an increasing proportion of our leisure time online, substituting for offline leisure (including television), and to a lesser extent work and sleep. Also with time use data, 
Goolsbee and Klenow (2006) estimates a consumer surplus of $\$ 3000$ per person-year in 2005. Goldfarb and Prince (2008) shows that this effect is heterogeneous. Overall, rich educated Americans are more likely to adopt and therefore overall consumer surplus disproportionately goes to the wealthy. At the same time, conditional on adoption, lower-income people spend more time online. Therefore, among adopters, consumer surplus (at least relative to overall consumption) is higher for lower-income people.

Many studies arrive at specific estimates of the consumer surplus from internet-related technologies. Greenstein and McDevitt (2011) measures the consumer surplus associated with broadband diffusion at $\$ 4.8$ to $\$ 6.7$ billion between 1999 and 2006. Brynjolfsson and Oh (2012) estimates the consumer surplus from free online services to be close to $\$ 100$ billion. Cohen et al. (2016) estimates billions of dollars in consumer surplus from the UberX car service alone. ${ }^{6}$

Brynjolfsson et al. (2017) provides perhaps the most comprehensive estimate of the consumer surplus of the internet by using (incentive compatible) choice experiments. For example, in one study, they asked people how much they would need to be paid in order to not have access to Facebook for a month. They then implemented the result by actually blocking their respondents' access to Facebook in exchange for payment. They estimate a value of Facebook of about $\$ 750$ per user per year, or $\$ 18$ billion for the United States. They also generated user-level survey estimates of the consumer surplus from other free online services such as search engines ( $\$ 16,000$ per user per year) and online video ( $\$ 900$ per user per year).

Before concluding, it is important to recognize that there are other, perhaps negative, changes to overall welfare that may result from shifts in internet consumption that are not captured by these surplus measures. Belo et al. (2013) shows a reduction in grades associated with school's adopting broadband, perhaps because online games distracted students.

\footnotetext{
${ }^{6}$ Greenstein and Nagle (2014) estimates an intangible benefit of digitization distinct from consumer surplus: The value of open source. It shows that open source software Apache generates at least $\$ 2$ billion in unmeasured benefits to the US economy.
} 
Bhuller et al. (2013) argues that internet diffusion may have increased sex crime, likely due to increased consumption of pornography (not because of reporting or matching between offenders and victims). Similarly, Chan et al. (2015) suggests an increase in racial hate crimes associated with the internet, and Falck et al. (2014) suggests that internet availability reduces voter turnout in elections.

\section{Conclusions}

Across a variety of fields, economists examine how digital technologies change economic activity. While these papers often have different perspectives and cite different literatures, a core theme is that digitization has reduced a number of specific economic costs. We have identified five such costs: Search, reproduction, transportation, tracking, and verification. These themes inform our understanding of the nature of digital economic activity, and of the interaction between digital and non-digital settings.

In defining the scope of this article, we drew boundaries. For example, we did not discuss work on skill-biased technical change. Because skill-bias is not primarily driven by the storage of information in bits, and because there are several other reviews of that literature, we instead refer to Katz and Autor (1999), Acemoglu (2002), Goldin and Katz (2008), and Acemoglu and Autor (2012). Similarly, we limit the discussion of the digital technology growth accounting literature, referring the reader to Jorgenson et al. (2008) and Van Reenen et al. (2010). We also limited our discussion on three topics that have already

received reviews in the Journal of Economic Literature: privacy (Acquisti et al., 2016), online auctions (Bajari and Hortacsu, 2004), and telecommunications pricing and universal service Vogelsang (2003).

This overview highlights that changes to economic behavior that result from the change of costs inherent in the digital context are not as obvious as basic economic models might imply. Key open questions remain with respect to each of the cost changes highlighted. 
Further, other categories of costs may shift downwards as digital technology evolves. 


\section{References}

Aaltonen, A. and S. Seiler (2016). Cumulative growth in user-generated content production: Evidence from wikipedia. Management Science 62(7), 2054-2069.

Acemoglu, D. (2002). Technical change, inequality, and the labor market. Journal of Economic Literature 40(1), 7-72.

Acemoglu, D., P. Aghion, C. LeLarge, J. V. Reenan, and F. Zilibotti (2007). Technology, information and the decentralization of the firm. Quarterly Journal of Economics 122, 1759-1799.

Acemoglu, D. and D. Autor (2012). Handbook of Labor Economics, Volume 4, Chapter 12, pp. 1043-1171. Elsevier.

Acemoglu, D., D. Laibson, and J. A. List (2014, May). Equalizing superstars: The internet and the democratization of education. American Economic Review 104(5), 523-27.

Acquisti, A. and C. M. Fong (2013). An experiment in hiring discrimination via online social networks. Mimeo, CMU.

Acquisti, A. and R. Gross (2009). Predicting social security numbers from public data. Proceedings of the National Academy of Sciences.

Acquisti, A., C. R. Taylor, and L. Wagman (2016). The economics of privacy. Journal of Economic Literature.

Acquisti, A. and C. Tucker (2014). Guns, privacy and crime. Mimeo, MIT.

Acquisti, A. and H. R. Varian (2005). Conditioning prices on purchase history. Marketing Science 24(3), 367-381. 
Adams, W. and J. L. Yellen (1976). Commodity bundling and the burden of monopoly. The Quarterly Journal of Economics 90(3), 475-498.

Agrawal, A., C. Catalini, and A. Goldfarb (2015). Crowdfunding: Geography, social networks, and the timing of investment decisions. Journal of Economics 83 Management Strategy 24(2), 253-274.

Agrawal, A. and A. Goldfarb (2008). Restructuring research: Communication costs and the democratization of university innovation. American Economic Review 98(4), 1578-90.

Agrawal, A., N. Lacetera, and E. Lyons (2016). Does standardized information in online markets disproportionately benefit job applicants from less developed countries? Journal of International Economics 103, 1 - 12.

Aguiar, L. and J. Waldfogel (2015). Streaming reaches flood stage: Does spotify stimulate or depress music sales? Working Paper, University of Minnesota.

Aguiar, L. and J. Waldfogel (2016). Digitization, copyright, and the welfare effects of music trade. Working Paper, University of Minnesota.

Aker, J. C. (2010). Information from markets near and far: Mobile phones and agricultural markets in niger. American Economic Journal: Applied Economics 2(3), 46-59.

Akerman, A., I. Gaarder, and M. Mogstad (2015). The skill complementarity of broadband internet. The Quarterly Journal of Economics 130(4), 1781.

Alaveras, G. and B. Martens (2015, August). International Trade in Online Services. JRC Working Papers on Digital Economy 2015-08, Joint Research Centre (Seville site).

Allcott, H. and M. Gentzkow (2017, May). Social media and fake news in the 2016 election. Journal of Economic Perspectives 31(2), 211-36. 
Anderson, C. (2006). The Long Tail. Hyperion.

Anderson, E. T., N. M. Fong, D. I. Simester, and C. E. Tucker (2010). How sales taxes affect customer and firm behavior: The role of search on the internet. Journal of Marketing Research 47(2), 229-239.

Anderson, J. E. and E. van Wincoop (2004). Trade costs. Journal of Economic Literature 42(3), 691-751.

Anderson, S. P. and A. de Palma (2009). Information congestion. RAND Journal of Economics 40(4), 688-709.

Anderson, S. P. and A. de Palma (2013, July). Shouting to Be Heard in Advertising. Management Science 59(7), 1545-1556.

Anderson, S. P. and J. S. Gans (2011, November). Platform siphoning: Ad-avoidance and media content. American Economic Journal: Microeconomics 3(4), 1-34.

Anenberg, E. and E. Kung (2015). Information technology and product variety in the city: The case of food trucks. Journal of Urban Economics 90,60 - 78 .

Antweiler, W. and M. Z. Frank (2004). Is all that talk just noise? The information content of internet stock message boards. Journal of Finance 59(3), 1259-1294.

Arnosti, N., M. Beck, and P. Milgrom (2016). Adverse selection and auction design for internet display advertising. American Economic Review 106(10), 2852-66.

Athey, S., E. Calvano, and J. S. Gans (2014). The impact of the internet on advertising markets for news media. Rotman School of Management Working Paper (2180851).

Athey, S., C. Catalini, and C. E. Tucker (2017). The digital privacy paradox: Small money, small costs, small talk. Working Paper, MIT. 
Athey, S. and J. S. Gans (2010, May). The impact of targeting technology on advertising markets and media competition. American Economic Review 100(2), 608-13.

Athey, S., M. Mobius, and J. Pal (2017, January). The impact of news aggregators on internet news consumption: The case of localization. Technical Report 3353.

Athey, S. and S. Stern (2002, Autumn). The impact of information technology on emergency health care outcomes. RAND Journal of Economics 33(3), 399-432.

Autor, D. H. (2001, March). Wiring the labor market. Journal of Economic Perspectives $15(1), 25-40$.

Ayres, I., M. Banaji, and C. Jolls (2015). Race effects on ebay. RAND Journal of Economics 46(4), 891-917.

Ba, S. and P. Pavlou (2002). Evidence of the effect of trust building technology in electronic markets: Price premiums and buyer behavior. MIS Quarterly 26, 243-268.

Bajari, P. and A. Hortacsu (2003). The winner's curse, reserve prices, and endogenous entry: Empirical insights from ebay auctions. RAND Journal of Economics 34(2), 329-355.

Bajari, P. and A. Hortacsu (2004). Economic insights from internet auctions. Journal of Economic Literature 42(2), 457-486.

Baker, G. P. and T. N. Hubbard (2003). Make versus buy in trucking: Asset ownership, job design, and information. American Economic Review 93(3), 551-572.

Baker, G. P. and T. N. Hubbard (2004). Contractibility and Asset Ownership: OnBoard Computers and Governance in U. S. Trucking. The Quarterly Journal of Economics 119(4), 1443-1479. 
Bakos, Yannis \& Brynjolfsson, E. (1999, 12). Bundling information goods: Price, profits, and efficiency. Management Science 45(12), 1613-1630.

Bakos, Y. (2001, March). The emerging landscape for retail e-commerce. Journal of Economic Perspectives 15(1), 69-80.

Bakos, Y. and E. Brynjolfsson (2000). Bundling and competition on the internet. Marketing Science 19(1), 63-82.

Balasubramanian, S. (1998). Mail versus mall: A strategic analysis of competition between direct marketers and conventional retailers. Marketing Science 17(3), 181-195.

Bar-Isaac, H., G. Caruana, and V. Cunat (2012). Search, design, and market structure. American Economic Review 102(2), 1140-60.

Barber, B. M. and T. Odean (2001, March). The internet and the investor. Journal of Economic Perspectives 15(1), 41-54.

Baye, M. R. and J. Morgan (2001a, June). Information gatekeepers on the internet and the competitiveness of homogeneous product markets. American Economic Review 91 (3), $454-474$.

Baye, M. R. and J. Morgan (2001b). Information gatekeepers on the internet and the competitiveness of homogenous product markets. American Economic Review 91 (3), 454474.

Baye, M. R., J. Morgan, and P. Scholten (2004a). Price dispersion in the small and in the large: Evidence from an internet price comparison site. Journal of Industrial Economics 52(4), 463-496. 
Baye, M. R., J. Morgan, and P. Scholten (2004b). Price dispersion in the small and the large: Evidence from an internet price comparison site. Journal of Industrial Economics 52(4), 463-496.

Bechtold, S. and C. Tucker (2014, December). Trademarks, triggers, and online search. Journal of Empirical Legal Studies $11(4)$.

Belo, R., P. Ferreira, and R. Telang (2013). Broadband in school: Impact on student performance. Management Science 60(2), 265-282.

Bergemann, D. and A. Bonatti (2011). Targeting in advertising markets: implications for offline versus online media. RAND Journal of Economics 42(3), 417-443.

Besen, S., P. Milgrom, B. Mitchell, and P. Srinagesh (2001). Advances in routing technologies and internet peering agreements. The American Economic Review 91(2), 292-296.

Bhargava, H. K. and V. Choudhary (2008). Research note: when is versioning optimal for information goods? Management Science 54(5), 1029-1035.

Bhuller, M., T. Havnes, and M. Leuven, Edwin; Mogstad (2013). Broadband internet: An information superhighway to sex crime? Review of Economic Studies 80(4), 1237-66.

Biasi, B. and P. Moser (2016, October). Effects of copyright on science: Evidence from the world war ii book republication program. Technical report.

Bitzer, J. and P. J. Schroder (2005, July). Bug-fixing and code-writing: The private provision of open source software. Information Economics and Policy 17(3), 389-406.

Blake, T., C. Nosko, and S. Tadelis (2015). Consumer heterogeneity and paid search effectiveness: A large scale field experiment. Econometrica 83(1), 155-174. 
Bloom, N., L. Garicano, R. Sadun, and J. Van Reenen (2014). The distinct effects of information technology and communication technology on firm organization. Management Science 60(12), 2859-2885.

Bloom, N., R. Sadun, and J. Van Reenen (2012, February). Americans do it better: Us multinationals and the productivity miracle. American Economic Review 102(1), 167201.

Blum, B. S. and A. Goldfarb (2006). Does the internet defy the law of gravity? Journal of International Economics 70(2), 384-405.

Böhme, R., N. Christin, B. Edelman, and T. Moore (2015). Bitcoin: Economics, technology, and governance. Journal of Economic Perspectives 29(2), 213-238.

Borenstein, S. and G. Saloner (2001, March). Economics and electronic commerce. Journal of Economic Perspectives 15(1), 3-12.

Bourreau, M., F. Kourandi, and T. Valletti (2015). Net neutrality with competing internet platforms. The Journal of Industrial Economics 63(1), 30-73.

Boxell, L., M. Gentzkow, and J. M. Shapiro (2017, March). Is the internet causing political polarization? evidence from demographics. Working paper, Brown University.

Brand, K., M. Gaynor, P. McAlvanah, D. Schmidt, and E. Schneirov (2014). Economics at the FTC: Office Supply Retailers Redux, Healthcare Quality Efficiencies Analysis, and Litigation of an Alleged Get-Rich-Quick Scheme. Review of Industrial Organization 45(4), $325-344$.

Brandimarte, L., A. Acquisti, and G. Loewenstein (2012). Misplaced confidences: Privacy and the control paradox. Social Psychological and Personality Science. 
Bresnahan, T. F., E. Brynjolfsson, and L. M. Hitt (2002, February). Information technology, workplace organization and the demand for skilled labor: Firm-level evidence. The Quarterly Journal of Economics 117(1), 339-76.

Bresnahan, T. F. and S. Greenstein (1996). Technical progress and co-invention in computing and in teh uses of computers. Brookings Papers on Economic Activity. Microeconomics, $1-78$.

Brown, J. and A. Goolsbee (2002). Does the internet make markets more competitive? Evidence from the life insurance industry. Journal of Political Economy 110(3), 481-507.

Brynjolfsson, E., F. Eggers, and A. Gannamaneni2017 (2017). Using massive online choice experiments to measure changes in well-being. Working paper, MIT.

Brynjolfsson, E. and L. Hitt (2003, November). Computing productivity: Firm-level evidence. Review of Economics and Statistics 85(4), 793-808.

Brynjolfsson, E., Y. Hu, and M. S. Rahman (2009). Battle of the retail channels: How product selection and geography drive cross-channel competition. Management Science 55(11), $1755-1765$.

Brynjolfsson, E., Y. Hu, and D. Simester (2011). Goodbye pareto principle, hello long tail: The effect of search costs on the concentration of product sales. Management Science 57(8), 1373-1386.

Brynjolfsson, E., Y. J. Hu, and M. D. Smith (2003, November). Consumer surplus in the digital economy: Estimating the value of increased product variety at online booksellers. Management Science 49(11), 1580-1596.

Brynjolfsson, E. and K. McElheran (2016, May). The rapid adoption of data-driven decisionmaking. American Economic Review 106(5), 133-39. 
Brynjolfsson, E. and J. Oh (2012). The attention economy: Measuring the value of free digital services on the internet. In ICIS. Association for Information Systems.

Brynjolfsson, E. and A. Saunders (2010). Wired for Innovation: How Information Technology is Reshaping the Economy. The MIT Press.

Brynjolfsson, E. and M. Smith (2000). Frictionless commerce? A comparison of internet and conventional retailers. Management Science 46(4), 563-585.

Cabral, L. (2012). Reputation on the internet. Oxford Handbook of the Digital Economy, $343-354$.

Cabral, L. and A. Hortacsu (2010). The dynamics of seller reputation: Evidence from ebay*. Journal of Industrial Economics 58(1), 54-78.

Caillaud, B. and B. Jullien (2003). Chicken \& egg: Competition among intermediation service providers. The RAND Journal of Economics 34(2), 309-328.

Cairncross, F. (1997). The Death of Distance. Harvard University Press. Cambridge, MA.

Calzada, J. and R. Gil (2016, September). What do news aggregators do? evidence from google news in spain and germany. Technical report.

Campbell, J., A. Goldfarb, and C. Tucker (2015). Privacy regulation and market structure. Journal of Economics \&5 Management Strategy 24(1), 47-73.

Campbell-Kelly, M. (2004). From Airline Reservations to Sonic the Hedgehog: A history of the software industry. MIT Press.

Carbajo, J., D. de Meza, and D. J. Seidmann (1990). A strategic motivation for commodity bundling. The Journal of Industrial Economics 38(3), 283-298. 
Carlton, D. W., J. S. Gans, and M. Waldman (2010, August). Why tie a product consumers do not use? American Economic Journal: Microeconomics 2(3), 85-105.

Castells, M. (2001). The Internet Galaxy: Reflections on the Internet, Business and Society. Oxford University Press, London.

Catalini, C. and J. S. Gans (2016). Some simple economics of the blockchain. SSRN Working Paper 2874598, https://papers.ssrn.com/sol3/papers.cfm?abstract_id=2874598.

Catalini, C. and C. Tucker (2016). Seeding the s-curve? the role of early adopters in diffusion.

Ceruzzi, P. E. (2003). A History of Modern Computing, Second edition. MIT Press.

Chan, J., A. Ghose, and R. Seamans (2015). The internet and racial hate crime: Offline spillovers from online access.

Chen, Y. (1997). Paying customers to switch. Journal of Economics $\& 3$ Management Strategy 6(4), 877-897.

Chen, Y. and T. Zhang (2011, November). Equilibrium price dispersion with heterogeneous searchers. International Journal of Industrial Organization 29(6), 645-54.

Chevalier, J. and D. Mayzlin (2006). The effect of word of mouth online: Online book reviews. Journal of Marketing Research 43(345-354).

Chiou, L. and C. Tucker (2012). How does the use of trademarks by third-party sellers affect online search? Marketing Science 31(5), 819-837.

Chiou, L. and C. Tucker (2013). Paywalls and the demand for news. Information Economics and Policy 25(2), 61-69.

Chiou, L. and C. Tucker (2017). Content aggregation by platforms: The case of the news media. Journal of Economics \& Management Strategy, n/a-n/a. 
Choi, J. and D. Bell (2011). Preference minorities and the internet. Journal of Marketing Research 58(3), 670-682.

Choi, J. P., D.-S. Jeon, and B.-C. Kim (2015, August). Net neutrality, business models, and internet interconnection. American Economic Journal: Microeconomics 7(3), 104-41.

Choi, T.-M. (2012). Handbook of Newsvendor Problems: Models, Extensions, and Applications, Volume 176 of International Series in Operations Research $\&$ Management Science. Springer Science and Business Media.

Chu, C. S., P. Leslie, and A. Sorensen (2011, February). Bundle-size pricing as an approximation to mixed bundling. American Economic Review 101(1), 263-303.

Clarke, G. R. (2008). Has the internet increased exports for firms from low and middleincome countries? Information Economics and Policy 20(1), 16 - 37.

Cohen, P., R. Hahn, J. Hall, S. Levitt, and R. Metcalfe (2016, September). Using big data to estimate consumer surplus: The case of uber. Working Paper 22627, National Bureau of Economic Research.

Cornes, R. and T. Sandler (1986). The theory of externalities, public goods, and club goods. Cambridge University Press.

Corrado, C., C. Hulten, and D. Sichel (2009). Intangible capital and u.s. economic growth. Review of Income and Wealth 55(3), 661-685.

Corrado, C. A. and C. R. Hulten (2010). How do you measure a "technological revolution"? The American Economic Review 100(2), 99-104.

Corts, K. (1998). Third-degree price discrimination in oligopoly: All-out competition and stretegic commitment. RAND Journal of Economics 29(2), 306-23. 
Cremer, J., P. Rey, and J. Tirole (2000). Connectivity in the commercial internet. Journal of Industrial Economics 48(4), 433-472.

Cristea, A. D. (2011). Buyer-seller relationships in international trade: Evidence from u.s. states' exports and business-class travel. Journal of International Economics 84(2), 207 $-220$.

Cullen, Z. and C. Farronato (2016). Outsourcing tasks online: Matching supply and demand on peer-to-peer internet platforms. HBS Working Paper.

Cullen, Z. and B. Pakzad-Hurson (2017). Equilibrium effects of pay transparency. Working paper, Harvard University.

Dana, James D., J. and E. Orlov (2014, November). Internet penetration and capacity utilization in the us airline industry. American Economic Journal: Microeconomics 6(4), $106-37$.

Danaher, B. and M. D. Smith (2014). Gone in 60 seconds: The impact of the megaupload shutdown on movie sales. International Journal of Industrial Organization 33, 1 - 8.

Danaher, B., M. D. Smith, and R. Telang (2013, June). Piracy and Copyright Enforcement Mechanisms, pp. 25-61. University of Chicago Press.

Danaher, B., M. D. Smith, R. Telang, and S. Chen (2014). The effect of graduated response anti-piracy laws on music sales: Evidence from an event study in france. The Journal of Industrial Economics 62(3), 541-553.

de Corniere, A. (2016). Search advertising. American Economic Journal: Microeconomics 8(3), 156-188. 
De Los Santos, B., A. Hortasu, and M. R. Wildenbeest (2012, May). Testing models of consumer search using data on web browsing and purchasing behavior. American Economic Review 102(6), 2955-80.

Dellarocas, C. (2003). The digitization of word of mouth: Promise and challenges of online feedback mechanisms. Management Science 49(10), 1407-1424.

Deneckere, R. J. and R. P. McAfee (1996). Damaged goods. Journal of Economics and Management Strategy 5(2), 149-74.

Diamond, P. (1971). A model of price adjustment. Journal of Economic Theory 3(2), $156-168$.

Dinerstein, M., L. Einav, J. Levin, and N. Sundaresan (2017). Consumer price search and platform design in internet commerce. Working paper, Stanford University.

Dinlersoz, E. and P. Pereira (2007). On the diffusion of electronic commerce. International Journal of Industrial Organization 25(3), 541-574.

Disdier, A.-C. and K. Head (2008). The puzzling persistence of the distance effect on bilateral trade. Review of Economics and Statistics 90(1), 37-48.

Doleac, J. L. (2017, January). The effects of dna databases on crime. American Economic Journal: Applied Economics 9(1), 165-201.

Doleac, J. L. and L. C. Stein (2013). The visible hand: Race and online market outcomes. The Economic Journal 123(572), F469-F492.

Draca, M., R. Sadun, and J. Van Reenen (2006). Productivity and ict: A review of the evidence. 
Dranove, D., C. Forman, A. Goldfarb, and S. Greenstein (2014). The trillion dollar conundrum: Complementarities and health information technology. American Economic Journal: Economic Policy 6(4), 239-270.

Dube, J.-P. and S. Misra (2017). Scalable price targeting. Working paper, University of Chicago.

Duch-Brown, N., L. Grzybowski, A. Romahn, and F. Verboven (2017). The impact of online sales on consumers and firms. evidence from consumer electronics. International Journal of Industrial Organization 52, $30-62$.

Economides, N. and B. E. Hermalin (2012). The economics of network neutrality. The RAND Journal of Economics 43(4), 602-629.

Economides, N. and P. Jeziorski (2017). Mobile money in tanzania. Marketing Science forthcoming.

Edelman, B. (2009). Prices and unpriced online markets. Journal of Economic Perspectives 23(3), 21-36.

Edelman, B. and M. Luca (2014, January). Digital discrimination: The case of airbnb.com.

Edelman, B., M. Ostrovsky, and M. Schwarz (2007, March). Internet advertising and the generalized second-price auction: Selling billions of dollars worth of keywords. American Economic Review 97(1), 242-259.

Eichengreen, B., R. Lafarguette, and A.Mehl (2016). Cables, sharks and servers: Technology and the geography of the foreign exchange market. NBER Working Paper 21884.

Einav, L., C. Farronato, J. Levin, and N. Sundaresan (2016, January). Auctions versus posted prices in online markets. Journal of Political Economy - forthcoming. 
Einav, L., C. Farronato, J. Levin, and N. Sundaresan (2017). Auctions versus posted prices in online markets. Journal of Political Economy.

Einav, L., P. Klenow, B. Klopack, J. Levin, L. Levin, and W. Best (2017). Assessing the gains from e-commerce. Working paper, Stanford University.

Einav, L., D. Knoepfle, J. Levin, and N. Sundaresan (2014). Sales taxes and internet commerce. American Economic Review 104(1), 1-26.

Ellison, G. (2011). Is peer review in decline? Economic Inquiry 49(3), 635-657.

Ellison, G. and S. F. Ellison (2005, June). Lessons about markets from the internet. Journal of Economic Perspectives 19(2), 139-158.

Ellison, G. and S. F. Ellison (2009a). Search, obfuscation, and price elasticities on the internet. Econometrica $77(2), 427-452$.

Ellison, G. and S. F. Ellison (2009b, August). Tax sensitivity and home state preferences in internet purchasing. American Economic Journal: Economic Policy 1(2), 53-71.

Ellison, G., S. F. Ellison, D. Liu, H. Zhang, and V. Bhattacharya (2014, September). Match quality, search, and the internet market for used books. Massachusetts Institute of Technology.

Ershov, D. (2017). The effect of consumer search costs on entry and quality in the mobile app market. Working Paper, University of Toronto.

Evans, D. S. (2009). The online advertising industry: Economics, evolution, and privacy. Journal of Economic Perspectives 23(3), 37-60.

Falck, O., R. Gold, and S. Heblich (2014, July). E-lections: Voting behavior and the internet. American Economic Review 104(7), 2238-65. 
Farrell, J. (2012). Can privacy be just another good. J. on Telecomm. Ef High Tech. L. 10, 251.

Farrell, J. and T. Simcoe (2012). Oxford Handbook of the Digital Economy, Chapter Four Paths to Compability, pp. 34-58. Oxford University Press.

Fay, S. and J. Xie (2008, July-August). Probabilistic goods: A creative way of selling products and services. Marketing Science 27(4), 674-90.

Ferreira, F. and J. Waldfogel (2013). Pop internationalism: has half a century of world music trade displaced local culture? Economic Journal 123(569), 634-664.

Fleder, D. M. and K. Hosanagar (2009, May). Blockbuster culture's next rise or fall: The impact of recommender systems on sales diversity. Managment Science 55(5), 697-712.

Forman, C., A. Ghose, and A. Goldfarb (2009). Competition between local and electronic markets: How the benefit of buying online depends on where you live. Management Science 55(1), 47-57.

Forman, C., A. Ghose, and B. Wiesenfeld (2009). Examining the relationship between reviews and sales: The role of reviewer identity disclosure in electronic markets. Information Systems Research 19(3). Special issue on the interplay between digital and social networks.

Forman, C., A. Goldfarb, and S. Greenstein (2005). How did location affect adoption of the commercial internet? Global village vs. urban leadership. Journal of Urban Economics 58(3), 389-420.

Forman, C., A. Goldfarb, and S. Greenstein (2008). Understanding the inputs into innovation: Do cities substitute for internal firm resources? Journal of Economics $\&$ Management Strategy 17(2), 295-316. 
Forman, C., A. Goldfarb, and S. Greenstein (2012). The internet and local wages: A puzzle. American Economic Review 102(1), 556-575.

Forman, C. and K. McElheran (2013). The digital reorganization of firm boundaries. Working paper, University of Toronto.

Forman, C. and N. van Zeebroeck (2012). From wires to partners: How the internet has fostered r\&d collaborations within firms. Management Science 58(8), 1549-1568.

Fradkin, A. (2017, March). Search, matching, and the role of digital marketplace design in enabling trade: Evidence from airbnb. Mimeo, MIT Sloan School of Business.

Fradkin, A. and C. Farronato (2016, January). Market structure with the entry of peer-topeer platforms: The case of hotels and airbnb.

Fradkin, A., E. Grewal, and D. Holtz (2017). The determinants of online review informativeness: Evidence from field experiments on airbnb. Working paper, MIT Sloan School of Management.

Freund, C. L. and D. Weinhold (2004). The effect of the internet on international trade. Journal of International Economics 62(1), 171-189.

Friedman, T. (2005). The World is Flat: A Brief History of the Twenty-First Century. New York: Farrar, Straus, and Giroux.

Fudenberg, D. and J. Tirole (1998). Upgrades, tradeins, and buybacks. The RAND Journal of Economics 29(2), 235-258.

Fudenberg, D. and J. Tirole (2000). Customer poaching and brand switching. The RAND Journal of Economics 31(4), 634-657. 
Fudenberg, D. and J. M. Villas-Boas (2007). Behaviour-Based Price Discrimination and Customer Recognition. Oxford: Elsevier Science.

Fudenberg, D. and J. M. Villas-Boas (2012, August). Price discrimination in the digital economy. Oxford Handbook of the Digital Economy.

Gal-Or, E. and A. Ghose (2005). The economic incentives for sharing security information. Information Systems Research 16(2), 186-208.

Gandal, N. (2006). The effect of native language on internet usage. International Journal of the Sociology of Language 182, 25-40.

Gans, J. S., A. Goldfarb, and M. Lederman (2016, August). Exit, tweets, and loyalty. (2889388).

Garicano, L. (2000). Hierarchies and the organization of knowledge in production. Journal of Political Economy 108(5), 874-904.

Garicano, L. (2010, July). Policemen, managers, lawyers: New results on complementarities between organization and information and communication technology. International Journal of Industrial Organization 28(4), 355-358.

Gaspar, J. and E. L. Glaeser (1998). Information technology and the future of cities. Journal of Urban Economics 43(1), 136-156.

Gentzkow, M. (2007, June). Valuing new goods in a model with complementarity: Online newspapers. American Economic Review 97, 713-744(32).

Gentzkow, M. (2014, May). Trading dollars for dollars: The price of attention online and offline. American Economic Review 104(5), 481-88. 
Gentzkow, M. and J. M. Shapiro (2011). Ideological segregation online and offline. Quarterly Journal of Economics 126(4), 1799-1839.

Gertner, R. H. and R. S. Stillman (2001). Vertical integration and internet strategies in the apparel industry. Journal of Industrial Economics 49(4), 441-461.

Ghani, E., W. R. Kerr, and C. Stanton (2014). Diasporas and outsourcing: Evidence from odesk and india. Management Science 60(7), 1677-1697.

Giorcelli, M. and P. Moser (2016, December). Copyrights and creativity: Evidence from italian operas. Journal of Economic Literature (O3, O33, O34, K11, N3).

Goetz, D. (2017). Competition and dynamic bargaining in the broadband industry. Working paper, University of Toronto.

Goldfarb, A. (2006). The (teaching) role of universities in the diffusion of the internet. International Journal of Industrial Organization 24(2), 203-225.

Goldfarb, A. (2014). What is different about online advertising? Review of Industrial Organization 44(2), 115-129.

Goldfarb, A., R. C. McDevitt, S. Samila, and B. S. Silverman (2015). The effect of social interaction on economic transactions: Evidence from changes in two retail formats. Management Science 61(12), 2963-2981.

Goldfarb, A. and J. Prince (2008). Internet adoption and usage patterns are different: Implications for the digital divide. Information Economics and Policy 20(1), 2-15.

Goldfarb, A. and C. Tucker (2011a, April). Advertising Bans and the Substitutability of Online and Offline Advertising. Journal of Marketing Research 48(2), 207-227. 
Goldfarb, A. and C. Tucker (2011b). Chapter 6 - online advertising. Volume 81 of Advances in Computers, pp. 289 - 315. Elsevier.

Goldfarb, A. and C. Tucker (2011c, May). Online display advertising: Targeting and obtrusiveness. Marketing Science 30, 389-404.

Goldfarb, A. and C. Tucker (2011d). Search engine advertising: Channel substitution when pricing ads to context. Management Science 57(3), 458-470.

Goldfarb, A. and C. Tucker (2011e). Substitution between offline and online advertising markets. Journal of Competition Law \& Economics 7(1), 37-44.

Goldfarb, A. and C. Tucker (2012a). Privacy and innovation. In Innovation Policy and the Economy, Volume 12, NBER Chapters. National Bureau of Economic Research, Inc.

Goldfarb, A. and C. Tucker (2012b). Shifts in privacy concerns. American Economic Review: Papers and Proceedings 102(3), 349-53.

Goldfarb, A. and C. E. Tucker (2011f). Privacy regulation and online advertising. Management Science 57(1), 57-71.

Goldin, C. and L. F. Katz (2008). The Race Between Education and Technology. Harvard University Press.

Goldmanis, M., A. Hortasu, C. Syverson, and n. Emre (2010). E-commerce and the market structure of retail industries*. The Economic Journal 120(545), 651-682.

Gomez-Herrera, E., B. Martens, and G. Turlea (2014). The drivers and impediments for cross-border e-commerce in the eu. Information Economics and Policy 28(C), 83-96.

Goolsbee, A. (2000, May). In a world without borders: The impact of taxes on internet commerce. Quarterly Journal of Economics 115(2), 561-576. 
Goolsbee, A. (2001). Competition in the computer industry: Online versus retail. Journal of Industrial Economics 49(4), 487-99.

Goolsbee, A. and P. J. Klenow (2006, May). Valuing consumer products by the time spent using them: An application to the internet. American Economic Review 96(2), 108-113.

Gordon, B., F. Zettelmeyer, N. Bhargava, and D. Chapsky (2016, 7). A comparison of approaches to advertising measurement: Evidence from big field experiments at facebook.

Gordon, L. A. and M. P. Loeb (2002). The economics of information security investment. ACM Transactions on Information and System Security (TISSEC) 5(4), 438-457.

Gorodnichenko, Y. and O. Talavera (2017). Price setting in online markets: Basic facts, international comparisons, and cross-border integration. American Economic Review 107(1), 249-282.

Greenstein, D. (2000). Building and delivering the virtual world: Commercializing services for internet access. The Journal of Industrial Economics 48, 391-411.

Greenstein, S. (2015). How the Internet Became Commercial. Princeton University Press.

Greenstein, S. and R. McDevitt (2011). The broadband bonus: Estimating broadband internet's economic value. Telecommunications Policy 35(7), 617-632.

Greenstein, S. and F. Nagle (2014). Digital dark matter and the economic contribution of Apache. Research Policy 43(4), 623-631.

Greenstein, S., M. Peitz, and T. Valletti (2016, May). Net neutrality: A fast lane to understanding the trade-offs. Journal of Economic Perspectives 30(2), 127-50.

Greenstein, S. and F. Zhu (2012). Is Wikipedia biased? American Economic Review 102(3), 343-348. 
Hafner, K. and M. Lyon (1996). where wizards stay up late. Simon and Schuster Paperbacks.

Hagiu, A. (2012). Oxford Handbook of the Digital Economy, Chapter Software Platforms, pp. 59-82. Oxford University Press.

Hagiu, A. and B. Jullien (2011). Why do intermediaries divert search? The RAND Journal of Economics 42(2), 337-362.

Halaburda, H. and Y. Yehezkel (2013, August). Platform competition under asymmetric information. American Economic Journal: Microeconomics 5(3), 22-68.

Hall, J., C. Kendrick, and C. Nosko (2016). The effects of uber's surge pricing: A case study. Technical report.

Haltiwanger, J. and R. S. Jarmin (2000). Understanding the Digital Economy: Data, Tools, and Research, Chapter Measuring the Digital Economy, pp. 13-33. MIT Press.

Hampton, K. and B. Wellman (2003). Neighboring in netville: How the internet supports community and social capital in a wired suburb. City \& Community 2(4), 277-311.

Hart, O. D. and J. Tirole (1988). Contract renegotiation and coasian dynamics. The Review of Economic Studies 55(4), 509-540.

Heald, P. (2009). Does the song remain the same? : an empirical study of bestselling musical compositions (1913-1932) and their use in cinema (1968-2007). Case Western Reserve Law Review.

Henkel, J. (2009). Champions of revealingthe role of open source developers in commercial firms. Industrial and Corporate Change 18(3), 435.

Hermalin, B. and M. Katz (2006, September). Privacy, property rights and efficiency: The economics of privacy as secrecy. Quantitative Marketing and Economics 4(3), 209-239. 
Hirschman, A. O. (1970, January). Exit, Voice, and Loyalty: Responses to Decline in Firms, Organizations, and States. Harvard University Press.

Hollenbeck, B. (2016). Online reputation mechanisms and the decreasing value of brands. UCLA Working paper.

Honka, E. (2014). Quantifying search and switching costs in the us auto insurance industry. The RAND Journal of Economics 45(4), 847-884.

Hortacsu, A., F. A. Martinez-Jerez, and J. Douglas (2009). The geography of trade in online transactions: Evidence from eBay and Mercadolibre. American Economic Journal: Microeconomics 1(1), 53-74.

Horton, J. J. and R. J. Zeckhauser (2016). Owning, using and renting: Some simple economics of the 'sharing economy'. NBER Working Paper No. 22029.

Hossain, T. and J. Morgan (2006). ... plus shipping and handling: Revenue (non) equivalence in field experiments on ebay. Advances in Economic Analysis 6 Policy 5(2).

Houser, D. and J. Wooders (2005). Reputation in auctions: Theory and evidence from ebay. Journal of Economics and Management Strategy 15, 353-369.

Hui, X. (2017). E-comemrce platforms and international trade: A large-scale field experiment. Working paper, MIT-Sloan School of Management.

Hui, X., M. Saeedi, Z. Shen, and N. Sundaresan (2016). Reputation and regulations: Evidence from ebay. Management Science 62(12), 3604-3616.

Jensen, R. (2007). The digital provide: Information (technology), market performance, and welfare in the South Indian fisheries sector. Quarterly Journal of Economics, 879-924. 
Jin, G. Z. and A. Kato (2006). Price, quality, and reputation: Evidence from an online field experiment. RAND Journal of Economics 37(4), 983-1005.

Jin, G. Z. and A. Kato (2007). Dividing online and offline: A case study. Review of Economic Studies 74 (3), 981-1004.

Johnson, G. (2014). The impact of privacy policy on the auction market for online display advertising. Available at SSRN 2333193.

Johnson, J. P. (2002). Open source software: Private provision of a public good. Journal of Economics 83 Management Strategy 11(4), 637-662.

Johnson, J. P. (2013). Targeted advertising and advertising avoidance. RAND Journal of Economics 44(1), 128-144.

Jorgenson, D. W., M. S. Ho, and K. J. Stiroh (2008, March). A retrospective look at the u.s. productivity growth resurgence. Journal of Economic Perspectives 22(1), 3-24.

Jullien, B. (2012). Oxford Handbook of the Digital Economy, Chapter Two-Sided B to B Platforms, pp. 161-185. Oxford University Press.

Katz, L. F. and D. Autor (1999). Handbook of Labor Economics, Volume 3, Chapter 26, pp. 1463-1555. Elsevier.

Kim, J.-H. and L. Wagman (2015). Screening incentives and privacy protection in financial markets: a theoretical and empirical analysis. The RAND Journal of Economics 46(1), $1-22$.

Kolko, J. (2012). Broadband and local growth. Journal of Urban Economics 71(1), 100-113.

Krautheim, S. (2012). Heterogeneous firms, exporter networks and the effect of distance on international trade. Journal of International Economics 87(1), 27 - 35. Symposium on the Global Dimensions of the Financial Crisis. 
Kremer, M., C. Brannen, and R. Glennerster (2013). The challenge of education and learning in the developing world. Science 340(6130), 297-300.

Kroft, K. and D. G. Pope (2014). Does Online Search Crowd Out Traditional Search and Improve Matching Efficiency? Evidence from Craigslist. Journal of Labor Economics 32(2), $259-303$.

Krugman, P. (1979). A model of innovation, technology transfer, and the world distribution of income. Journal of Political Economy, 253-266.

Kuhn, P. and H. Mansour (2014). Is internet job search still ineffective? Economic Journal 124(581), 1213-1233.

Kuhn, P. and M. Skuterud (2004, March). Internet job search and unemployment durations. American Economic Review 94(1), 218-232.

Kummer, M. E., O. Slivko, and X. M. Zhang (2015, November). Economic downturn and volunteering: Do economic crises affect content generation on wikipedia? Technical Report 15-078.

Laffont, J.-J., S. Marcus, P. Rey, and J. Tirole (2001, May). Internet peering. American Economic Review 91(2), 287-291.

Laffont, J.-J., S. Marcus, P. Rey, and J. Tirole (2003). Internet interconnection and the off-net-cost pricing principle. The RAND Journal of Economics 34(2), 370-390.

Lambrecht, A. and K. Misra (2017). Fee or free: When should firms charge for online content? Management Science 63(4), 1150-1165.

Lambrecht, A. and C. Tucker (2013). When does retargeting work? Information specificity in online advertising. Journal of Marketing Research 50(5), 561-576. 
Lambrecht, A. and C. E. Tucker (2016). Algorithmic bias? an empirical study into apparent gender-based discrimination in the display of stem career ads.

Leamer, E. E. (2007, March). A flat world, a level playing field, a small world after all, or none of the above? a review of thomas 1 friedman's the world is flat. Journal of Economic Literature 45(1), 83-126.

Lee, J., J. S. McCullough, and R. J. Town (2013). The impact of health information technology on hospital productivity. RAND Journal of Economics 44(3), 545-568.

Lee, R. S. and T. Wu (2009, September). Subsidizing creativity through network design: Zero-pricing and net neutrality. Journal of Economic Perspectives 23(3), 61-76.

Lemley, M. (2003). Place and cyberspace. California Law Review 91(2), 521-542.

Lenard, T. M. and P. H. Rubin (2009). In Defense of Data: Information and the Costs of Privacy. Technology Policy Institute Working Paper.

Lendle, A., M. Olarreaga, S. Schropp, and P. Vzina (2016, 03). There Goes Gravity: eBay and the Death of Distance. Economic Journal 126(591), 406-441.

Lerner, J., P. A. Pathak, and J. Tirole (2006, May). The dynamics of open-source contributors. American Economic Review 96(2), 114-118.

Lerner, J. and J. Tirole (2002). Some simple economics of open source. The Journal of Industrial Economics 50(2), 197-234.

Levin, J. and P. Milgrom (2010, May). Online advertising: Heterogeneity and conflation in market design. American Economic Review 100(2), 603-07.

Lewis, R., J. M. Rao, and D. H. Reiley (2015, April). Measuring the Effects of Advertising: The Digital Frontier, pp. 191-218. University of Chicago Press. 
Lewis, R. A. and J. M. Rao (2015). The unfavorable economics of measuring the returns to advertising. The Quarterly Journal of Economics 130(4), 1941.

Lewis, R. A. and D. H. Reiley (2014). Online ads and offline sales: measuring the effect of retail advertising via a controlled experiment on yahoo! Quantitative Marketing and Economics 12(3), 235-266.

Li, X., M. MacGarvie, and P. Moser (2015, September). Dead poet's property - how does copyright influence price? Working Paper 21522, National Bureau of Economic Research.

Lieber, E. and C. Syverson (2012). Oxford Handbook of the Digital Economy, Chapter Online versus offline competition, pp. 189-223. Oxford University Press.

Liebowitz, S. J. (2008). Research notetesting file sharing's impact on music album sales in cities. Management Science 54(4), 852-859.

Liebowitz, S. J. and A. Zentner (2012). Clash of the titans: Does internet use reduce television viewing? Review of Economics and Statistics 94(1), 234-245.

Livingston, J. (2005). How valuable is a good reputation? a sample selection model of internet auctions. The Review of Economics and Statistics 87(3), 453-465.

Loginova, O. (2001). Real and virtual competition. Journal of Industrial Economics 57(2), $319-342$.

Luca, M. (2011). Reviews, reputation, and revenue: The case of yelp. com. Harvard Business School NOM Unit Working Paper (12-016).

Luca, M. and G. Zervas (2016, December). Fake It Till You Make It: Reputation, Competition, and Yelp Review Fraud. Management Science 62(12), 3412-3427. 
Lucking-Reiley, D. (1999, December). Using field experiments to test equivalence between auction formats: Magic on the internet. American Economic Review 89(5), 1063-1080.

Lucking-Reiley, D., D. Bryan, N. Prasad, and D. Reeves (2007). Pennies from ebay: The determinants of price in online auctions. Journal of Industrial Economics 55(2), 223-233.

Lucking-Reiley, D. and D. F. Spulber (2001, March). Business-to-business electronic commerce. Journal of Economic Perspectives 15(1), 55-68.

Lynch, J. G. and D. Ariely (2000). Wine online: Search costs affect competition on price, quality, and distribution. Marketing Science 19(1), 83-103.

Lyons, E. (2017). Team production in international labor markets: Experimental evidence from the field. American Economic Journal: Applied Economics.

MacGarvie, M. and P. Moser (2015). Copyright and the profitability of authorship. Economic Analysis of the Digital Economy, 357.

MacKie-Mason, J. K. and H. Varian (1994, September). Economic faqs about the internet. Journal of Economic Perspectives 8(3), 75-96.

Marrano, M. G., J. Haskel, and G. Wallis (2009). What happened to the knowledge economy? ict, intangible investment, and britain's productivity record revisited. Review of Income and Wealth 55(3), 686-716.

Marthews, A. and C. Tucker (2014). Government surveillance and internet search behavior. Available at SSRN 2412564.

Maskin, E. and J. Riley (1984). Monopoly with incomplete information. The RAND Journal of Economics 15(2), 171-96. 
Mayzlin, D., Y. Dover, and J. Chevalier (2014). Promotional reviews: An empirical investigation of online review manipulation. American Economic Review 104(8), 2421-55.

McCabe, M. J. and C. M. Snyder (2015). Does online availability increase citations? theory and evidence from a panel of economics and business journals. The Review of Economics and Statistics 97(1), 144-165.

McCullough, J. S., S. T. Parente, and R. Town (2016). Health information technology and patient outcomes: The role of information and labor coordination. RAND Journal of Economics 47(1), 207-236.

McElheran, K. (2014). Delegation in multi-establishment firms: Evidence from I.T. purchasing. Journal of Economics \&3 Management Strategy $23(2), 225-258$.

McElheran, K. and W. Jin (2017). Economies before scale: I.t. investment and performance in young firms. Working paper, University of Toronto.

Mcknight, L. W. and J. P. Bailey (1998). Internet Economics. MIT Press.

McLuhan, M. (1964). Understanding Media: The Extensions of Man. New York: McGrawHill.

Melnik, M. I. and J. Alm (2002). Does a sellers ecommerce reputation matter? evidence from ebay auctions. The Journal of Industrial Economics 50(3), 337-349.

Miller, A. and C. Tucker (2009, July). Privacy protection and technology adoption: The case of electronic medical records. Management Science 55(7), 1077-1093.

Miller, A. and C. Tucker (2011). Can healthcare information technology save babies? Journal of Political Economy (2), 289-324. 
Miller, A. and C. Tucker (2014). Privacy protection, personalized medicine and genetic testing. Mimeo, MIT.

Moore, T., R. Clayton, and R. Anderson (2009, September). The economics of online crime. Journal of Economic Perspectives 23(3), 3-20.

Mortimer, J. H., C. Nosko, and A. Sorensen (2012). Supply responses to digital distribution: Recorded music and live performances. Information Economics and Policy 24(1), 3-14.

Morton, F. S., F. Zettelmeyer, and J. Silva-Risso (2003). Consumer information and discrimination: Does the internet affect the pricing of new cars to women and minorities? Quantitative Marketing and Economics 1(1), 65-92.

Moshary, S., T. Blake, K. Sweeney, and S. Tadelis (2017, April). Price salience and product choice.

Mustonen, M. (2005). When does a firm support substitute open source programming? Journal of Economics \& Management Strategy 14(1), 121-139.

Nagaraj, A. (2016, July). The private impact of public maps: Landsat satellite imagery and gold exploration. Technical report.

Nagaraj, A. (2017). Does copyright affect reuse? evidence from the google books digitization project. Management Science, forthcoming.

Nocke, V., M. Peitz, and K. Stahl (2007). Platform ownership. Journal of the European Economic Association 5(6), 1130-1160.

Nosko, C. and S. Tadelis (2017). The limits of reputation in platform markets: An empirical analysis and field experiment. Working Paper, University of California Berkeley. 
Oberholzer-Gee, F. and K. Strumpf (2007). The effect of file sharing on record sales: An empirical analysis. Journal of Political Economy 115, 1-42.

Ockenfels, A., D. Reiley, and A. Sadrieh (2006, December). Online auctions.

Orlov, E. (2011). How does the internet influence price dispersion? evidence from the airline industry. Journal of Industrial Economics 59(1), 21-37.

Overman, H. G., S. Redding, and A. J. Venables (2003). Handbook of International Trade, Chapter The Economic Geography of Trade, Production, and Income: A Survey of Empirics, pp. 353387. Blackwell Publishing.

Parker, C., K. Ramdas, and N. Savva (2016). Is it enough? evidence from a natural experiment in indias agriculture markets. Management Science 62(9), $2481-2503$.

Peitz, M. and P. Waelbroeck (2006). Why the music industry may gain from free downloading - the role of sampling. International Journal of Industrial Organization 24(5), 907-913.

Peitz, M. and J. Waldfogel (2012). Oxford Digital Handbooks, Chapter Digital Piracy: Empirics. Oxford University Press.

Petty, R. D. (2000). Marketing without consent: Consumer choice and costs, privacy, and public policy. Journal of Public Policy 8 Marketing 19(1), 42-53.

Peukert, C., J. Claussen, and T. Kretschmer (2017). Piracy and box office movie revenues: Evidence from megaupload. International Journal of Industrial Organization 52, 188 215.

Pope, D. G. and J. R. Sydnor (2011). Whats in a picture?: Evidence of discrimination from prosper.com. Journal of Human Resources 46(1), 53-92. 
Pozzi, A. (2013). E-commerce as a stockpiling technology: Implications for consumer savings. International Journal of Industrial Organization 31(6), 677 - 689. The Economics of Information and Communication Technologies (ICT).

Prince, J. (2007). The beginning of online/retail competition and its origins: An application to personal computers. International Journal of Industrial Organization 25(1), 139-156.

Quan, T. W. and K. R. Williams (2017). Product variety, across-market demand heterogeneity, and the value of online retail. Working paper, Yale University.

Rao, A. (2015). Online content pricing: Purchase and rental markets. Marketing Science $34(3), 430-451$.

Rao, J. M. and D. H. Reiley (2012, April). The economics of spam. Journal of Economic Perspectives 26(3), 87-110.

Reimers, I. (2016). Can private copyright protection be effective? evidence from book publishing. The Journal of Law and Economics 59(2), 411-440.

Reis, F., P. Ferreira, M. G. de Matos, and M. Smith (2015). Patterns of substitution between internet and television in the era of media streaming-evidence from a randomized experiment. Technical report, Working paper. Carnegie Mellon University.

Resnick, P. and R. Zeckhauser (2002). Trust Among Strangers in Internet Transactions: Empirical Analysis form eBay Auctions, pp. 667-719. Amsterdam: Elsevier Science.

Rob, R. and J. Waldfogel (2006). Piracy on the high c's: Music downloading, sales displacement, and social welfare in a sample of college students. Journal of Law and Economics 49(1), 29-62.

Rob, R. and J. Waldfogel (2007). Piracy on the silver screen*. The Journal of Industrial Economics 55(3), 379-395. 
Rochet, J.-C. and J. Tirole (2003). Platform competition in two-sided markets. Journal of the European Economic Association 1(4), 990-1029.

Rosen, S. (1981). The economics of superstars. The American Economic Review 71(5), $845-858$.

Rosenblat, T. and M. Mobius (2004). Getting closer or drifting apart? Quarterly Journal of Economics 119(3), 971-1009.

Roth, A. E. and A. Ockenfels (2002, September). Last-minute bidding and the rules for ending second-price auctions: Evidence from ebay and amazon auctions on the internet. American Economic Review 92(4), 1093-1103.

Rysman, M. (2007). An empirical analysis of payment card usage. The Journal of Industrial Economics 55(1), 1-36.

Rysman, M. and T. Simcoe (2008). Patents and the performance of voluntary standardsetting organizations. Management Science 54(11), 1920-1934.

Salop, S. (1979). Monopolistic competition with outside goods. Bell Journal of Economics 10, 141-146.

Savage, S. J. and D. M. Waldman (2009). Ability, location and household demand for internet bandwidth. International Journal of Industrial Organization 27(2), 166 - 174.

Scott, S. L. and H. R. Varian (2015, April). Bayesian Variable Selection for Nowcasting Economic Time Series, pp. 119-135. University of Chicago Press.

Seamans, R. and F. Zhu (2013). Responses to entry in multi-sided markets: The impact of craigslist on local newspapers. Management Science 60(2), 476-493. 
Shapiro, C. and H. R. Varian (1998). Information rules: A strategic guide to the network economy. Harvard Business Press.

Shiller, B. and J. Waldfogel (2011). Music for a song: An empirical look at uniform pricing and its alternatives. The Journal of Industrial Economics 59(4), 630-660.

Shiller, B. and J. Waldfogel (2017). Will ad blocking break the internet? Working paper, University of Minnesota.

Shin, J. and K. Sudhir (2010, July-August). A customer management dilemma: When is it profitable to reward one's own customers? Marketing Science 21(4), 671-89.

Simcoe, T. (2012, February). Standard setting committees: Consensus governance for shared technology platforms. American Economic Review 102(1), 305-36.

Simonov, A., C. Nosko, and J. M. Rao (2017, April). Competition and crowd-out for brand keywords in sponsored search. Journal of Economic Literature.

Sinai, T. and J. Waldfogel (2004). Geography and the internet: Is the internet a substitute or a complement for cities? Journal of Urban Economics 56(1), 1-24.

Smith, M. D., J. Bailey, and E. Brynjolfsson (2001). Understanding the Digital Economy: Data, Tools, and Research, Chapter Understanding Digital Markets: Review and Assessment, pp. 99-136. MIT Press.

Smith, M. D. and E. Brynjolfsson (2001). Consumer decision-making at an internet shopbot: Brand still matters. The Journal of Industrial Economics 49(4), 541-558.

Soloveichik, R. (2010, May). Artistic originals as a capital asset. American Economic Review 100(2), 110-14.

Solow, R. M. (1987, July). We'd better watch out. The New York Times, 36. 
Stanton, C. and C. Thomas (2016). Landing the first job: The value of intermediaries in online hiring. Review of Economic Studies 83(2).

Stigler, G. (1961). The economics of information. Journal of Political Economy 69.

Stigler, G. J. (1963). Public regulation of the securities markets. The Journal of Business 37, 117-117.

Sunstein, C. (2001). Echo Chambers: Bush v. Gore, Impeachement, and Beyond. Princeton University Press.

Tadelis, S. (1999). What's in a name? reputation as a tradeable asset. The American Economic Review 89(3), 548-563.

Takayama, L. (1994). The welfare implications of unauthorized reproduction of intellectual property in presence of demand network externalities. Journal of Industrial Economics $42(2)$.

Tambe, P. and L. M. Hitt (2012, April). Now it's personal: Offshoring and the shifting skill composition of the u.s. information technology workforce. Management Science 58(4), $678-695$.

Tambe, P., L. M. Hitt, and E. Brynjolfsson (2012, May). The extroverted firm: How external information practices affect innovation and productivity. Management Science 58(5), 84359.

Taylor, C. and L. Wagman (2014). Consumer privacy in oligopolistic markets: Winners, losers, and welfare. International Journal of Industrial Organization 34, 80 - 84.

Taylor, C. R. (2004, Winter). Consumer privacy and the market for customer information. RAND Journal of Economics 35(4), 631-650. 
Tucker, C. (2012a, May). The economics of advertising and privacy. International Journal of Industrial Organization 30(3), 326-329.

Tucker, C. (2012b). Patent trolls and technology diffusion. In Standards, Patents and Innovations. National Bureau of Economic Research, Inc.

Tucker, C. (2014, October). Social networks, personalized advertising, and privacy controls. Journal of Marketing Research 51(5), 546-562.

Tucker, C. (2015). Handbook of Media Economics Volume 1A, Chapter Privacy and the Internet. North Holland.

Tucker, C. and S. Yu (2017). Technology and inequality: The role of mobile applications in the inequality of treatment of customer complaints. Mimeo, MIT.

Tucker, C. and J. Zhang (2011). How does popularity information affect choices? a field experiment. Management Science 57(5), 828-842.

Van Reenen, J., N. Bloom, M. Draca, T. Kretschmer, R. Sadun, H. Overman, and M. Schankerman (2010). The economic impact of ict. Final report.

Varian, H. (2007). Position auctions. International Journal of Industrial Organization 25(6), $1163-1178$.

Varian, H., F. Wallenberg, and G. Woroch (2005). The demographics of the do-not-call list. IEEE Security and Privacy 3(1), 34-39.

Varian, H. R. (1980). A model of sales. The American Economic Review 70(4), 651-659.

Varian, H. R. (2005, June). Copying and copyright. Journal of Economic Perspectives 19(2), $121-138$. 
Varian, H. R. (2010, May). Computer mediated transactions. American Economic Review $100(2), 1-10$.

Villas-Boas, J. M. (2004). Price cycles in markets with customer recognition. The RAND Journal of Economics 35(3), 486-501.

Vogelsang, I. (2003, September). Price regulation of access to telecommunications networks. Journal of Economic Literature 41(3), 830-862.

Waldfogel, J. (2010). Music file sharing and sales displacement in the itunes era. Information Economics and Policy 22(4), 306-314.

Waldfogel, J. (2012). Copyright research in the digital age: Moving from piracy to the supply of new products. American Economic Review 102(3), 337-342.

Waldfogel, J. (2015). First degree price discrimination goes to school. Journal of Industrial Economics 63(4), 569-597.

Waldfogel, J. (2016). Cinematic explosion: New products, unpredictabilty and realized quality in the digital era. The Journal of Industrial Economics 64(4), 755-772.

Waldfogel, J. and L. Chen (2006). Does information undermine brand? Information intermediary use and preference for branded web retailers. Journal of Industrial Economics 54(4), $425-449$.

Waldfogel, J. and I. Reimers (2015). Storming the gatekeepers: Digital disintermediation in the market for books. Information Economics and Policy $31(\mathrm{C}), 47-58$.

Wallsten, S. (2013, October). What are we not doing when we're online. Working Paper 19549, National Bureau of Economic Research. 
Weyl, E. G. (2010, September). A price theory of multi-sided platforms. American Economic Review $100(4), 1642-72$.

White, A. (2013). Search engines: Left side quality versus right side profits. International Journal of Industrial Organization 31(6), 690 - 701. The Economics of Information and Communication Technologies (ICT).

Williams, H. L. (2013). Intellectual property rights and innovation: Evidence from the human genome. Journal of Political Economy 121(1), 1-27.

Xu, L., T. Nian, and L. Cabral (2016, April). What makes geeks tick? a study of stack overflow careers. Technical report.

Yang, H. (2013). Targeted search and the long tail effect. The RAND Journal of Economics $44(4), 733-756$.

Zentner, A. (2006). Measuring the effect of file sharing on music purchases. The Journal of Law \& Economics 49(1), 63-90.

Zervas, G., D. Proserpio, and J. W. Byers (2016). The rise of the sharing economy: Estimating the impact of airbnb on the hotel industry. Journal of Marketing Research 0(ja), null.

Zettelmeyer, Florian, F. S. M. and J. Silva-Risso (2001). Internet car retailing. Journal of Industrial Economics 49(4), 501-519.

Zhang, J. and P. Liu (2012). Rational herding in microloan markets. Management Science 58(5), 892-912.

Zhang, L. (2016). Intellectual property strategy and the long tail: Evidence from the recorded music industry. Management Science 0(0), null. 
Zhang, X. M. and F. Zhu (2011, June). Group size and incentives to contribute: A natural experiment at chinese wikipedia. American Economic Review 101(4), 1601-15. 